\title{
An Update on Screening Strategies for Gestational Diabetes Mellitus: A Narrative Review
}

\author{
Caro Minschart (ID) \\ Kaat Beunen' \\ Katrien Benhalima ${ }^{1,2}$ \\ 'Clinical and Experimental Endocrinology, \\ Department of Chronic Diseases and \\ Metabolism, KU Leuven, Leuven, 3000, \\ Belgium; ${ }^{2}$ Department of Endocrinology, \\ University Hospital Gasthuisberg, KU \\ Leuven, Leuven, 3000, Belgium
}

\begin{abstract}
Gestational diabetes mellitus (GDM) is a frequent medical complication during pregnancy. Screening and diagnostic practices for GDM are inconsistent across the world. This narrative review includes data from 87 observational studies and randomized controlled trials (RCTs), and aims to give an overview of the current evidence on screening strategies and diagnostic criteria for GDM. Screening in early pregnancy remains controversial and studies show conflicting results on the benefit of screening and treatment of GDM in early pregnancy. Implementing the one-step "International Association of Diabetes and Pregnancy Study Groups" (IADPSG) screening strategy at 24-28 weeks often leads to a substantial increase in the prevalence of GDM, without conclusive evidence regarding the benefits on pregnancy outcomes compared to a two-step screening strategy with a glucose challenge test (GCT). In addition, RCTs are needed to investigate the impact of treatment of GDM diagnosed with IADPSG criteria on long-term maternal and childhood outcomes. Selective screening using a risk-factor-based approach could be helpful in simplifying the screening algorithm but carries the risk of missing significant proportions of GDM cases. A two-step screening method with a $50 \mathrm{~g}$ GCT and subsequently a $75 \mathrm{~g}$ oral glucose tolerance test (OGTT) with IADPSG could be an alternative to reduce the need for an OGTT. However, to have an acceptable sensitivity to screen for GDM with the IADPSG criteria, the threshold of the GCT should be lowered from 7.8 to $7.2 \mathrm{mmol} / \mathrm{L}$. A pragmatic approach to screen for GDM can be implemented during the COVID-19 pandemic, using fasting plasma glucose (FPG), HbA1c or even random plasma glucose (RPG) to reduce the number of OGTTs needed. However, usual guidelines and care should be resumed as soon as the COVID pandemic is controlled.
\end{abstract}

Keywords: gestational diabetes mellitus, screening, diabetes, pregnancy

\section{Introduction}

Gestational diabetes mellitus (GDM) is defined as diabetes diagnosed in the second or third trimester of pregnancy provided that overt diabetes was excluded before pregnancy or at the latest in early pregnancy. ${ }^{1}$ Most international guidelines such as the American Diabetes Association (ADA) and World Health Organization (WHO) recommend to screen for overt diabetes at first prenatal visit, since these women have (untreated) a very high risk for pregnancy complications and need treatment with insulin. $^{1,2}$ The prevalence of GDM is rising globally and if left untreated, the condition is associated with an increased risk of fetal and maternal complications such as preeclampsia and large-for-gestational age (LGA) infants. ${ }^{3,4}$ Shortly after delivery, the glucose values generally normalize, but women with GDM and their offspring are at increased risk to develop type 2 diabetes (T2DM) later in life. ${ }^{5-7}$ Two
Correspondence: Caro Minschart Clinical and Experimental Endocrinology, Department of Chronic Diseases and Metabolism, KU Leuven, Herestraat 49, Leuven, 3000, Belgium

Tel +3216345134

Email caro.minschart@kuleuven.be 
large randomized controlled trials (RCTs) have confirmed that treatment of GDM between 24 and 28 weeks of pregnancy results in a lesser degree of perinatal complications, mainly in the frequency of LGA and preeclampsia., However, controversy exists regarding the optimal screening and diagnostic approach for GDM. These controversies are situated in various domains such as the use of different diagnostic criteria for GDM, selective screening based on risk factors versus universal screening, one-step screening or two-step screening, the use of alternate screening methods like fasting plasma glucose (FPG) or $\mathrm{HbAlc}$, the potential benefit of screening for GDM in early pregnancy, screening for GDM in specific populations or circumstances, such as in women who underwent bariatric surgery or in the COVID-19 pandemic setting.

The initial diagnostic criteria of GDM were established by O' Sullivan almost 60 years ago. ${ }^{8}$ In the 1980 s, Carpenter and Coustan modified these criteria and proposed a two-step screening method, consisting of a $50 \mathrm{~g}$ glucose challenge test (GCT) and subsequent a $3 \mathrm{~h} 100 \mathrm{~g}$ oral glucose tolerance test (OGTT) if screening threshold of the GCT was exceeded. ${ }^{9}$ However, these criteria were chosen to identify women at high risk for the development of diabetes after pregnancy and not necessarily to identify pregnancies with an increased risk for adverse perinatal outcomes. ${ }^{10}$ In 1980 , the $2 \mathrm{~h} 75 \mathrm{~g}$ OGTT was established as the diagnostic test for diabetes and glucose intolerance, and the WHO extended this recommendation to pregnant women. However, the ADA and many other medical associations continued to follow the National Diabetes Data Group (NDDG) recommendation to use the $3 \mathrm{~h} 100 \mathrm{~g}$ OGTT, because the $2 \mathrm{~h} \mathrm{75g}$ OGTT had been little investigated during pregnancy. In 2010, the "International Association of Diabetes and Pregnancy Study Groups" (IADPSG) made an attempt to unify the guidelines for screening and diagnosis of GDM by recommending a universal one-step approach with a $75 \mathrm{~g}$ OGTT and more stringent diagnostic criteria. ${ }^{11}$ This recommendation was based on the results of the "Hyperglycemia and Adverse Pregnancy Outcomes" (HAPO) study, which demonstrated a continuous and graded relationship between maternal hyperglycemia and the risk for adverse perinatal outcomes. ${ }^{12}$ However, the adoption of the IADPSG criteria remains controversial due to the significant increase in the number of women categorized and treated as GDM. Recently, a review on current screening guidelines for GDM assessed 16 different guidelines across the world and confirmed that there is an ongoing lack of consensus, with inconsistencies mainly focusing on the screening process (one-step vs two-step) and criteria for the OGTT. ${ }^{13}$ In addition, a survey in 2015 on screening practices in Europe demonstrated that the majority of European societies still recommended risk-factor-based screening and about one-third recommended a universal one-step approach with a $75 \mathrm{~g}$ OGTT and IADPSG criteria. ${ }^{14}$ This lack of consensus creates problems in addressing and comparing prevalence, outcomes, efficacy of treatment, and follow-up of GDM.

This comprehensive review provides an update on screening strategies and diagnostic criteria for GDM in early and late pregnancy. In addition, evidence on pragmatic approaches to screen for GDM after bariatric surgery and in a pandemic setting such as COVID-19 are discussed.

\section{Methods}

A literature search was conducted on PubMed between January 2021 and March 2021. Cross-sectional studies, case-control studies, cohort studies, and RCTs were considered for this narrative review. The populations studied included pregnant women with or without GDM, in which we evaluated the effects of the implementation of different protocols, guidelines or programs for screening for GDM, compared with the absence of screening, or compared with other protocols, guidelines or programs for screening. Screening strategies included universal versus selective screening, one-step versus two-step screening, early versus late screening, screening after bariatric surgery, and screening in times of COVID-19. We excluded animal studies, descriptive designs (case series and case reports), studies with a low quality (no method section, no p-values mentioned), and articles written in a language other than English, French or Dutch. The search was not limited to a certain time period. The following search strategy was used in PubMed: ((“Screening”[Title/ Abstract] OR “screening strateg*"[Title/Abstract]) AND ("diabetes, gestational”[MeSH Terms:noexp] OR "Gestational diabetes"[Title/Abstract] OR "Pregnancy-Induced Diabetes"[Title/Abstract] OR "gestational hyperglycemia"[Title/Abstract] OR "hyperglycemic pregnancy"[Title/Abstract] OR "PregnancyInduced Diabetes"[Title/Abstract] OR "gestational hyperglycemia"[Title/Abstract] OR "gestational glucose intolerance"[Title/Abstract])) AND (((“Universal”[Title/ Abstract] OR “one-step"[Title/Abstract]) AND "Screening”[Title/Abstract]) OR ("risk factor"[Title/ 
Abstract] AND “Screening"[Title/Abstract]) OR ("twostep"[Title/Abstract] AND “Screening”[Title/Abstract]) OR ("early screening"[Title/Abstract] OR "in early pregnancy”[Title/Abstract]) OR ("Bariatric Surgery"[MeSH Terms] OR "Gastric Bypass"[MeSH Terms] OR "Gastrectomy"[MeSH Terms] OR "Bariatric Surgery"[Title/Abstract] OR "Gastric Bypass"[Title/Abstract] OR "Gastrectomy"[Title/ Abstract]) OR (“COVID-19”[MeSH Terms] OR "SARSCoV-2"[MeSH Terms] OR “COVID-19"[Title/Abstract] OR "SARS-CoV-2"[Title/Abstract] OR “2019-nCoV" [Title/Abstract] OR “Coronavirus Disease-19"[Title/ Abstract])).

In addition, the reference lists of all identified articles were examined to identify studies not captured by the electronic search. As this is not a systematic review of the literature, we reported our results in a descriptive manner.

\section{Overview of the Included Publications}

We identified 737 articles of which 164 were selected as possibly relevant. After examination of the full-text articles, 87 studies were included in this review (Figure 1).

\section{Screening in Early Pregnancy}

The Impact of Screening in Early Pregnancy on Pregnancy Outcomes

The aim of early screening would be to identify women at low or high risk for GDM later in pregnancy. In addition, this might help to identify women who already have GDM to allow earlier treatment and potentially improve maternal and neonatal outcomes.

Early testing in pregnancy for diabetes will lead to the identification of hyperglycemia under the threshold of overt diabetes. These women could be labeled as early GDM. However, the IADPSG criteria have not been validated for use in early pregnancy. Observational studies show conflicting results as to whether screening for earlyonset GDM can improve pregnancy outcomes (Table 1). Several studies reported an improvement in maternal and neonatal outcomes. ${ }^{15-18}$ A retrospective cohort study by Bartha et al found that early glucose intolerance screening with a GCT could avoid diabetes-related complications such as polyhydramnios, fetal anomalies and preterm birth in women diagnosed with GDM. ${ }^{16}$ Ryan et al demonstrated that early screening improved the primary composite outcome [emergency caesarean section, neonatal

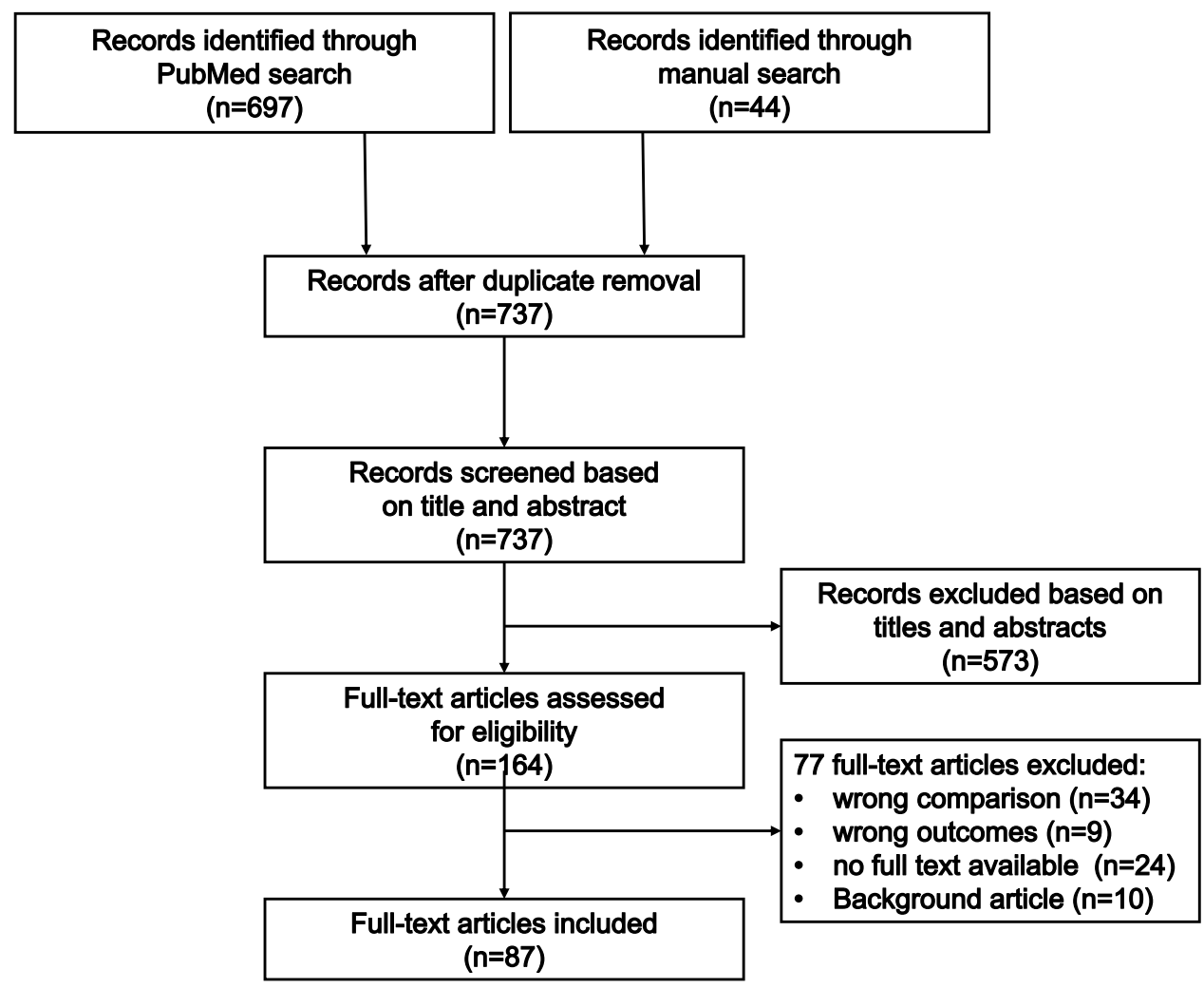

Figure I The literature search and selection process. 
Table I Screening for GDM in Early Pregnancy

\begin{tabular}{|l|l|l|l|l|l|l|l|}
\hline $\begin{array}{l}\text { Author, } \\
\text { Year/Country } \\
\text { (Ref.) }\end{array}$ & Design & $\begin{array}{l}\text { Subjects } \\
(\mathrm{N})\end{array}$ & $\begin{array}{l}\text { Study } \\
\text { Population }\end{array}$ & $\begin{array}{l}\text { Timeframe } \\
\text { Early Testing } \\
\text { (Weeks) }\end{array}$ & $\begin{array}{l}\text { GDM Diagnosis } \\
\text { Criteria }\end{array}$ & Comparison & Main Results \\
\hline
\end{tabular}

\section{Observational studies}

\begin{tabular}{|c|c|c|c|c|c|c|c|}
\hline $\begin{array}{l}\text { Bartha, 2002/ } \\
\text { Spain }^{16}\end{array}$ & $\begin{array}{l}\text { Retrospective } \\
\text { cohort study }\end{array}$ & 424 & $\begin{array}{l}\text { Women with } \\
\text { GDM }\end{array}$ & $\begin{array}{l}\text { First antenatal } \\
\text { visit (early) }\end{array}$ & $\begin{array}{l}50 \mathrm{~g} \text { GCT } \\
\text { followed by, if } \\
\text { abnormal, a } 3 \mathrm{~h} \\
100 \mathrm{~g} \text { OGTT/ } \\
\text { GDM diagnosis if } \\
\geq 2 \text { values } \\
\text { abnormal ( } \geq .5 .8 \text {, } \\
10.6,9.2,8.1 \\
\mathrm{mmol} / \mathrm{L})\end{array}$ & $\begin{array}{l}\text { Earlier vs later } \\
\text { (24-28 weeks) } \\
\text { screening }\end{array}$ & $\begin{array}{l}\text { Early glucose } \\
\text { intolerance } \\
\text { screening with } \\
\text { a GCT could avoid } \\
\text { diabetes-related } \\
\text { complications in } \\
\text { women diagnosed } \\
\text { with GDM }\end{array}$ \\
\hline $\begin{array}{l}\text { Riskin, 2009/ } \\
\text { Israel| }^{32}\end{array}$ & $\begin{array}{l}\text { Retrospective } \\
\text { study }\end{array}$ & 6129 & $\begin{array}{l}\text { Singleton } \\
\text { pregnancies } \\
>24 \text { weeks in } \\
\text { mothers } \\
\text { without ODIP } \\
\text { or FTFPG } \\
\geq 5.8 \mathrm{mmol} / \mathrm{L}\end{array}$ & $<13$ weeks & $\begin{array}{l}50 \mathrm{~g} \mathrm{GCT} \mathrm{followed} \\
\text { by, if abnormal, } 3 \mathrm{~h} \\
100 \mathrm{~g} \mathrm{OGTT} \text { at } 24 \\
28 \text { weeks } / \mathrm{CC} \\
\text { criteria and GCT } \\
\geq 11.1 \mathrm{mmol} / \mathrm{L}\end{array}$ & $\begin{array}{l}\text { FPG categories } \\
(<4.2,4.2-4.4, \\
4.5-4.7,4.8-5.0, \\
5.1-5.2,5.3-5.5 \\
\text { and } 5.6-5.8 \\
\mathrm{mmol} / \mathrm{L})\end{array}$ & $\begin{array}{l}\text { Higher FTFPG in } \\
\text { early pregnancy } \\
\text { increased the risk } \\
\text { of adverse } \\
\text { pregnancy } \\
\text { outcomes }\end{array}$ \\
\hline $\begin{array}{l}\text { van Leeuwen, } \\
2010 / \text { the } \\
\text { Netherlands }{ }^{40}\end{array}$ & $\begin{array}{l}\text { Prospective } \\
\text { cohort study }\end{array}$ & 995 & $\begin{array}{l}\text { Singleton } \\
\text { pregnancies in } \\
\text { women } \\
\text { without ODIP } \\
<20 \text { weeks }\end{array}$ & $<20$ weeks & $\begin{array}{l}50 \mathrm{~g} \mathrm{GCT} \text { and RPG } \\
\text { at } 24-28 \text { weeks } \\
\text { followed by } 2 \mathrm{~h} \\
75 \mathrm{~g} \text { OGTT if RPG } \\
\geq 6.8 \mathrm{mmol} / \mathrm{L} \text { or } \\
\mathrm{l} \mathrm{h} \geq 7.8 \mathrm{mmol} / \mathrm{L} / \\
\text { WHO } 1999 \\
\text { criteria }\end{array}$ & $50 \mathrm{~g} \mathrm{GCT}$ vs RPG & $\begin{array}{l}\text { Use of a clinical } \\
\text { prediction model is } \\
\text { an accurate } \\
\text { method to identify } \\
\text { women at } \\
\text { increased risk for } \\
\text { GDM, and could be } \\
\text { used to select } \\
\text { women } \\
\text { for additional } \\
\text { testing for GDM }\end{array}$ \\
\hline $\begin{array}{l}\text { Teede, } 201 \text { I/ } \\
\text { Australia }^{41}\end{array}$ & $\begin{array}{l}\text { Retrospective } \\
\text { study }\end{array}$ & 4276 & $\begin{array}{l}\text { Singleton } \\
\text { pregnancies }\end{array}$ & 12-15 weeks & $\begin{array}{l}\text { Two-step method: } \\
\text { GCT followed by, } \\
\text { if abnormal, a } 2 \mathrm{~h} \\
75 \mathrm{~g} \text { OGTT at } 28 \\
\text { weeks/ADIPS } \\
\text { criteria }\end{array}$ & $\begin{array}{l}\text { Derivation (used } \\
\text { to develop } \\
\text { a simple } \\
\text { predictor scoring } \\
\text { tool that } \\
\text { specified GDM } \\
\text { risk based on } \\
\text { identified clinical } \\
\text { risk factors) vs } \\
\text { validation group }\end{array}$ & $\begin{array}{l}\text { The risk } \\
\text { prediction tool, } \\
\text { derived from risk } \\
\text { factors in early } \\
\text { pregnancy, } \\
\text { enables simple } \\
\text { identification of } \\
\text { women at an } \\
\text { increased risk of } \\
\text { developing GDM }\end{array}$ \\
\hline $\begin{array}{l}\text { Zhu, 20I3/ } \\
\text { China }^{34}\end{array}$ & $\begin{array}{l}\text { Retrospective } \\
\text { cohort study }\end{array}$ & 14,039 & $\begin{array}{l}\text { All pregnant } \\
\text { women } \\
\text { without ODIP }\end{array}$ & $\begin{array}{l}\text { First antenatal } \\
\text { visit }(<24 \\
\text { weeks })\end{array}$ & $\begin{array}{l}2 \mathrm{~h} 75 \mathrm{~g} \text { OGTT at } \\
24-28 \text { weeks/ } \\
\mathrm{MOH} \text { China } \\
\text { criteria (fasting, } \\
\geq 5.10 \mathrm{mmol} / \mathrm{L} \text {; I } \\
\mathrm{h}, \geq 10.00 \mathrm{mmol} / \mathrm{L} \text {; } \\
\text { and } 2 \mathrm{~h}, \geq 8.50 \\
\mathrm{mmol} / \mathrm{L} \text { ) }\end{array}$ & $\begin{array}{l}6 \text { FPG groups } \\
(<4.1,4.1-4.59 \text {, } \\
4.60-5.09,5.10- \\
5.59,5.6-6.09 \text {, } \\
6.10-6.99 \mathrm{mmol} / \\
\text { L) }\end{array}$ & $\begin{array}{l}\text { Only } 30.3 \% \text { of } \\
\text { women who had } \\
\text { a FPG of } \geq 5.1 \\
\mathrm{mmol} / \mathrm{L} \text { still had } \\
\text { a FPG of } \geq 5.1 \\
\mathrm{mmol} / \mathrm{L} \text { at } 24-28 \\
\text { weeks }\end{array}$ \\
\hline
\end{tabular}

(Continued) 
Table I (Continued).

\begin{tabular}{|c|c|c|c|c|c|c|c|}
\hline $\begin{array}{l}\text { Author, } \\
\text { Year/Country } \\
\text { (Ref.) }\end{array}$ & Design & $\begin{array}{l}\text { Subjects } \\
\text { (N) }\end{array}$ & $\begin{array}{l}\text { Study } \\
\text { Population }\end{array}$ & $\begin{array}{l}\text { Timeframe } \\
\text { Early Testing } \\
\text { (Weeks) }\end{array}$ & $\begin{array}{l}\text { GDM Diagnosis } \\
\text { Criteria }\end{array}$ & Comparison & Main Results \\
\hline $\begin{array}{l}\text { Alunni, 20I5/ } \\
\text { US }^{20}\end{array}$ & $\begin{array}{l}\text { Retrospective } \\
\text { cohort study }\end{array}$ & 2652 & $\begin{array}{l}\text { Singleton } \\
\text { pregnancies in } \\
\text { women } \\
\text { without ODIP }\end{array}$ & $\leq 24$ weeks & $\begin{array}{l}\text { Early screening: } \\
\text { (I) HbAIc 5.7- } \\
6.4 \% \text { or FPG } 5.1- \\
6.9 \mathrm{mmol} / \mathrm{L} \text { at } \leq 24 \\
\text { weeks, (2) one } \\
\text { abnormal value on } \\
\text { a } 2 \mathrm{~h} 75 \mathrm{~g} \text { OGTT at } \\
24-28 \text { weeks if } \\
\text { normal early } \\
\text { screening } \\
\text { Standard } \\
\text { approach: Ih } 50 \mathrm{~g} \\
\text { GCT followed by } \\
\text { a } 3 \mathrm{~h} \mathrm{I00g} \mathrm{OGTT/} \\
\text { CC Criteria }\end{array}$ & $\begin{array}{l}\text { Early screening } \\
\text { vs standard two- } \\
\text { step ACOG } \\
\text { approach }\end{array}$ & $\begin{array}{l}\text { Implementing } \\
\text { early screening } \\
\text { for GDM gave no } \\
\text { significant } \\
\text { difference in } \\
\text { neonatal } \\
\text { outcomes }\end{array}$ \\
\hline $\begin{array}{l}\text { Hong, 2016/ } \\
\text { US }^{21}\end{array}$ & $\begin{array}{l}\text { Retrospective } \\
\text { cohort study }\end{array}$ & 569 & $\begin{array}{l}\text { Singleton } \\
\text { GDM } \\
\text { pregnancies } \\
\text { with } \geq 1 \\
\text { indication for } \\
\text { early screening } \\
\text { (GDM or } \\
\text { macrosomia in } \\
\text { a prior } \\
\text { pregnancy or } \\
\text { obesity) }\end{array}$ & $<20$ weeks & $\begin{array}{l}\text { Ih } 50 \mathrm{~g} \text { GCT } \\
\text { followed by a } 3 \mathrm{~h} \\
\text { I00g OGTT if the } \\
\text { former was } \geq 7.5 \\
\mathrm{mmol} / \mathrm{L} / \mathrm{CC} \\
\text { criteria }\end{array}$ & $\begin{array}{l}\text { Early }(<20 \\
\text { weeks) vs } \\
\text { routine ( }>24 \\
\text { weeks) screening }\end{array}$ & $\begin{array}{l}\text { Early GDM } \\
\text { screening was not } \\
\text { associated with } \\
\text { a decreased risk } \\
\text { of adverse } \\
\text { perinatal } \\
\text { outcomes }\end{array}$ \\
\hline $\begin{array}{l}\text { Sweeting, 2017/ } \\
\text { Australia }^{39}\end{array}$ & $\begin{array}{l}\text { Retrospective } \\
\text { cohort study }\end{array}$ & 3098 & $\begin{array}{l}\text { High risk } \\
\text { women }\end{array}$ & $<24$ weeks & $\begin{array}{l}\text { Universal testing } \\
\text { at } 24-28 \text { weeks } \\
\text { with } 2 \mathrm{~h} 75 \mathrm{~g} \\
\text { OGTT or } 50 \mathrm{~g} \\
\text { GCT and, if } \\
\text { positive, } \\
\text { a subsequent } \\
\text { OGTT/ADIPS } \\
\text { criteria }\end{array}$ & $\begin{array}{l}\text { Early GDM (<24 } \\
\text { weeks) vs } \\
\text { standard GDM } \\
\text { ( } \geq 24 \text { weeks) }\end{array}$ & $\begin{array}{l}\mathrm{HbAlc}>5.9 \% \\
\text { early in pregnancy } \\
\text { identified an } \\
\text { increased risk of } \\
\text { LGA, } \\
\text { macrosomia, } \\
\text { C-section, and } \\
\text { hypertensive } \\
\text { disorders in } \\
\text { standard GDM }\end{array}$ \\
\hline $\begin{array}{l}\text { Mañe, 2017/ } \\
\text { Spain }\end{array}$ & $\begin{array}{l}\text { Prospective } \\
\text { multi-ethnic } \\
\text { cohort study }\end{array}$ & 1228 & $\begin{array}{l}\text { Singleton } \\
\text { pregnancies in } \\
\text { women } \\
\text { without ODIP }\end{array}$ & First trimester & $\begin{array}{l}\text { Two-step } \\
\text { approach: } 50 \mathrm{~g} \\
\text { GCT followed by, } \\
\text { if abnormal, a } 3 \mathrm{~h} \\
100 \mathrm{~g} \text { OGTT at } \\
24-28 \text { weeks/ } \\
\text { NDDG criteria }\end{array}$ & $\begin{array}{l}\mathrm{HbAlc} \geq 5.9 \% \text { vs } \\
5.9-6.4 \%\end{array}$ & $\begin{array}{l}\text { Early } \mathrm{HbAlc} \\
\geq 5.9 \% \text { identified } \\
\text { women at high } \\
\text { risk of adverse } \\
\text { pregnancy } \\
\text { outcomes } \\
\text { independently of } \\
\text { GDM diagnosis } \\
\text { later in pregnancy }\end{array}$ \\
\hline
\end{tabular}

(Continued) 
Table I (Continued).

\begin{tabular}{|c|c|c|c|c|c|c|c|}
\hline $\begin{array}{l}\text { Author, } \\
\text { Year/Country } \\
\text { (Ref.) }\end{array}$ & Design & $\begin{array}{l}\text { Subjects } \\
\text { (N) }\end{array}$ & $\begin{array}{l}\text { Study } \\
\text { Population }\end{array}$ & $\begin{array}{l}\text { Timeframe } \\
\text { Early Testing } \\
\text { (Weeks) }\end{array}$ & $\begin{array}{l}\text { GDM Diagnosis } \\
\text { Criteria }\end{array}$ & Comparison & Main Results \\
\hline $\begin{array}{l}\text { Benaiges, 20I7/ } \\
\text { Spain }^{36}\end{array}$ & $\begin{array}{l}\text { Retrospective } \\
\text { analysis of } \\
\text { a non- } \\
\text { randomized } \\
\text { prospective } \\
\text { cohort }\end{array}$ & 1158 & $\begin{array}{l}\text { Women with } \\
\text { a singleton } \\
\text { pregnancy } \\
\text { without ODIP }\end{array}$ & $<12$ weeks & $\begin{array}{l}\text { Two-step method: } \\
50 \mathrm{~g} \mathrm{GCT} \\
\text { followed by a } 3 \mathrm{~h} \\
100 \mathrm{~g} \text { OGTT if the } \\
\text { former was } \\
\text { positive/NDDG } \\
\text { criteria }\end{array}$ & $\begin{array}{l}\text { First trimester } \\
\mathrm{HbAlc} \text { of }<4.8 \% \\
\text { vs } 4.8-5.5 \% \text { vs } \\
\geq 5.6 \%\end{array}$ & $\begin{array}{l}\text { HbAlc in early } \\
\text { pregnancy lacks } \\
\text { sensitivityl } \\
\text { specificity for use } \\
\text { as diagnostic test, } \\
\text { but could be useful } \\
\text { in simplifying the } \\
\text { diagnostic } \\
\text { algorithm for GDM }\end{array}$ \\
\hline $\begin{array}{l}\text { Hosseini, 2018/ } \\
\text { Iran }^{22}\end{array}$ & $\begin{array}{l}\text { Prospective } \\
\text { population- } \\
\text { based cohort } \\
\text { study }\end{array}$ & 929 & $\begin{array}{l}\text { Singleton } \\
\text { pregnancies }\end{array}$ & 6-14 weeks & $\begin{array}{l}\text { Universal } \\
\text { screening with } \\
\text { FPG for ODIP } \\
\text { and early GDM at } \\
6-14 \text { weeks. } 2 \mathrm{~h} \\
75 \text { g OGTT at } 24- \\
28 \text { weeks/ } \\
\text { IADPSG criteria }\end{array}$ & $\begin{array}{l}\text { Normal } \\
\text { pregnancy vs } \\
\text { early-onset } \\
\text { GDM (6-14 } \\
\text { weeks) vs late- } \\
\text { onset GDM (24- } \\
28 \text { weeks) }\end{array}$ & $\begin{array}{l}\text { Early-onset GDM } \\
\text { was associated } \\
\text { with poorer } \\
\text { pregnancy } \\
\text { outcomes }\end{array}$ \\
\hline $\begin{array}{l}\text { Ryan, 2018/ } \\
\text { UK }^{18}\end{array}$ & $\begin{array}{l}\text { Retrospective } \\
\text { clinical audit of } \\
\text { a prospectively } \\
\text { maintained } \\
\text { database }\end{array}$ & 576 & $\begin{array}{l}\text { High risk } \\
\text { singleton } \\
\text { pregnancies }\end{array}$ & $11-13$ weeks & $\begin{array}{l}\text { FPG/ } 2 \mathrm{~h} 75 \mathrm{~g} \\
\text { OGTT/SIGN } \\
2010 \text { thresholds }\end{array}$ & $\begin{array}{l}\text { Routine vs early } \\
\text { screening }\end{array}$ & $\begin{array}{l}\text { Early screening } \\
\text { improved the } \\
\text { pregnancy } \\
\text { outcomes, such as } \\
\text { emergency } \\
\text { C-section, } \\
\text { macrosomia and } \\
\text { neonatal } \\
\text { hypoglycemia }\end{array}$ \\
\hline $\begin{array}{l}\text { Bianchi, } 2019 / \\
\text { Italy }^{19}\end{array}$ & $\begin{array}{l}\text { Retrospective } \\
\text { study }\end{array}$ & 290 & $\begin{array}{l}\text { High risk } \\
\text { women }\end{array}$ & 16-18 weeks & $\begin{array}{l}\text { 2h 75g OGTT } \\
\text { (and FPG)/ } \\
\text { IADPSG criteria }\end{array}$ & $\begin{array}{l}\text { Early (16-18 } \\
\text { weeks) vs } \\
\text { standard ( } 24-28 \\
\text { weeks) screening }\end{array}$ & $\begin{array}{l}\text { Similar short- } \\
\text { term maternal- } \\
\text { fetal outcomes in } \\
\text { both groups }\end{array}$ \\
\hline Boe, $2019 / \mathrm{US}^{37}$ & $\begin{array}{l}\text { Retrospective } \\
\text { cohort study }\end{array}$ & 4144 & $\begin{array}{l}\text { Women } \\
\text { without } \\
\text { multiple } \\
\text { gestations } \\
\text { and second } \\
\text { deliveries }\end{array}$ & $\begin{array}{l}\text { First antenatal } \\
\text { visit }(<24 \\
\text { weeks })\end{array}$ & $\begin{array}{l}\text { HbAlc and/or } 3 \mathrm{~h} \\
\text { I00g OGTT/ } \\
\text { HbAIc } \geq 6.5 \% \\
\text { (ODIP) vs } 5.9- \\
6.4 \% \text { vs }<5.9 \% \text { and } \\
\text { CC criteria }\end{array}$ & $\begin{array}{l}\text { Early HbAlc vs } \\
\text { CC testing }\end{array}$ & $\begin{array}{l}\text { Early HbAlc as an } \\
\text { isolated test could } \\
\text { not replace } \\
\text { routine CC } \\
\text { testing for GDM } \\
\text { because of poor } \\
\text { sensitivity }\end{array}$ \\
\hline $\begin{array}{l}\text { Punnose, 2020/ } \\
\text { India }^{38}\end{array}$ & $\begin{array}{l}\text { Retrospective } \\
\text { cohort study }\end{array}$ & 2275 & $\begin{array}{l}\text { Singleton } \\
\text { pregnancies in } \\
\text { women } \\
\text { without ODIP }\end{array}$ & $\begin{array}{l}\text { First trimester } \\
\text { (before } 136 / 7 \\
\text { weeks) }\end{array}$ & $\begin{array}{l}\text { One-step } 2 \mathrm{~h} 75 \mathrm{~g} \\
\text { OGTT at }<24 \\
\text { weeks (in case of } \\
\text { risk factors) or at } \\
24-28 \text { weeks/ } \\
\text { IADPSG criteria }\end{array}$ & $\begin{array}{l}\mathrm{HbAlc}<5.2 \% \text { vs } \\
5.2-5.5 \% \text { vs } \\
\geq 5.6 \%\end{array}$ & $\begin{array}{l}\text { Early HbAlc is an } \\
\text { independent GDM } \\
\text { predictor in Asian } \\
\text { Indian women but } \\
\text { lacks sensitivity } \\
\text { and specificity for } \\
\text { use as a diagnostic } \\
\text { test }\end{array}$ \\
\hline
\end{tabular}

(Continued) 
Table I (Continued).

\begin{tabular}{|c|c|c|c|c|c|c|c|}
\hline $\begin{array}{l}\text { Author, } \\
\text { Year/Country } \\
\text { (Ref.) }\end{array}$ & Design & $\begin{array}{l}\text { Subjects } \\
\text { (N) }\end{array}$ & $\begin{array}{l}\text { Study } \\
\text { Population }\end{array}$ & $\begin{array}{l}\text { Timeframe } \\
\text { Early Testing } \\
\text { (Weeks) }\end{array}$ & $\begin{array}{l}\text { GDM Diagnosis } \\
\text { Criteria }\end{array}$ & Comparison & Main Results \\
\hline $\begin{array}{l}\text { Benhalima, } \\
\text { 2020/Belgium }{ }^{42}\end{array}$ & $\begin{array}{l}\text { Multi-centric } \\
\text { prospective } \\
\text { cohort study }\end{array}$ & 1843 & $\begin{array}{l}\text { Singleton } \\
\text { pregnancies } \\
\text { without ODIP } \\
\text { and history of } \\
\text { bariatric } \\
\text { surgery }\end{array}$ & 6-14 weeks & $\begin{array}{l}\text { Non-fasting GCT } \\
\text { and } 2 \mathrm{~h} 75 \mathrm{~g} \text { OGTT } \\
\text { at } 24-28 \text { weeks/ } \\
\text { IADPSG criteria }\end{array}$ & $\begin{array}{l}\text { Accuracy of the } \\
\text { developed } \\
\text { prediction model } \\
\text { using clinical and } \\
\text { biochemical risk } \\
\text { factors in early } \\
\text { pregnancy vs two } \\
\text { validated models } \\
\text { (van Leeuwen } \\
\text { and Teede) }\end{array}$ & $\begin{array}{l}\text { This prediction } \\
\text { model for GDM } \\
\text { had a moderate } \\
\text { accuracy and } \\
\text { could identify } \\
\text { women at risk for } \\
\text { GDM before or in } \\
\text { early pregnancy }\end{array}$ \\
\hline $\begin{array}{l}\text { Cosson, 2020/ } \\
\text { France }^{15}\end{array}$ & $\begin{array}{l}\text { Retrospective } \\
\text { study }\end{array}$ & 523 & $\begin{array}{l}\text { Women with } \\
\text { singleton } \\
\text { pregnancy and } \\
\text { without ODIP } \\
\text { and bariatric } \\
\text { surgery }\end{array}$ & $<22$ weeks & $\begin{array}{l}\text { FPG or } 2 \mathrm{~h} 75 \mathrm{~g} \\
\text { OGTT/ IADPSG } \\
\text { criteria }\end{array}$ & $\begin{array}{l}\text { Immediate care } \\
\text { vs no immediate } \\
\text { care for early } \\
\text { fasting } \\
\text { hyperglycemia }\end{array}$ & $\begin{array}{l}\text { Treating women } \\
\text { with early fasting } \\
\text { hyperglycemia, } \\
\text { especially when } \\
\text { FPG is } \geq 5.5 \\
\text { mmol/L, may } \\
\text { improve } \\
\text { pregnancy } \\
\text { outcomes }\end{array}$ \\
\hline $\begin{array}{l}\text { Liu, 2020/ } \\
\text { China }{ }^{17}\end{array}$ & $\begin{array}{l}\text { Prospective } \\
\text { cohort study }\end{array}$ & 522 & $\begin{array}{l}\text { Singleton } \\
\text { pregnancies }\end{array}$ & 18-20 weeks & $\begin{array}{l}\text { 2h 75g OGTT/ } \\
\text { IADPSG-20I5 } \\
\text { guidelines }\end{array}$ & $\begin{array}{l}4 \text { groups: NGT } \\
\text { (no GDM } \\
\text { diagnosis), } \\
\text { EGDM (GDM in } \\
\text { only early } \\
\text { OGTT), LGDM } \\
\text { (GDM in only } \\
\text { standard OGTT) } \\
\text { and GDM (GDM } \\
\text { diagnosis in both } \\
\text { OGTTs) }\end{array}$ & $\begin{array}{l}\text { Early GDM } \\
\text { diagnosis at } 18-20 \\
\text { weeks is } \\
\text { associated with } \\
\text { adverse outcomes }\end{array}$ \\
\hline $\begin{array}{l}\text { Benhalima, } \\
202 \text { I/Belgium } 33\end{array}$ & $\begin{array}{l}\text { Multi-centric } \\
\text { prospective } \\
\text { cohort study }\end{array}$ & 2006 & $\begin{array}{l}\text { Singleton } \\
\text { Pregnancies } \\
\text { without ODIP } \\
\text { and history of } \\
\text { bariatric } \\
\text { surgery }\end{array}$ & 6-14 weeks & $\begin{array}{l}\text { Non-fasting GCT } \\
\text { and a } 2 \mathrm{~h} 75 \mathrm{~g} \\
\text { OGTT at } 24-28 \\
\text { weeks/IADPSG } \\
\text { criteria }\end{array}$ & $\begin{array}{l}\mathrm{FPG} \geq 5.1-5.5 \\
\mathrm{mmol} / \mathrm{L} \text { in early } \\
\text { pregnancy vs } \\
\mathrm{FPG}<5.1 \mathrm{mmol} / \\
\mathrm{L} \text { in early } \\
\text { pregnancy }\end{array}$ & $\begin{array}{l}\text { Group with } \\
\text { increased FPG in } \\
\text { early pregnancy } \\
\text { had significantly } \\
\text { more NICU } \\
\text { admissions }\end{array}$ \\
\hline \multicolumn{8}{|l|}{ RCTs } \\
\hline $\begin{array}{l}\text { Osmundson, } \\
2016 / \text { US }^{27}\end{array}$ & RCT & 83 & $\begin{array}{l}\text { Women with } \\
\text { singleton } \\
\text { pregnancy } \\
\text { without ODIP, } \\
\text { with HbAIc } \\
5.7-6.4 \%\end{array}$ & $<14.0$ weeks & $\begin{array}{l}2 \mathrm{~h} 75-\mathrm{g} \text { OGTT at } \\
26-28 \text { weeks/ } \\
\text { IADPSG and } \\
\text { California Sweet } \\
\text { Success } \\
\text { Guidelines }\end{array}$ & $\begin{array}{l}\text { Usual care vs } \\
\text { early treatment } \\
\text { for GDM with } \\
\text { diet, BG } \\
\text { monitoring, and } \\
\text { insulin as needed }\end{array}$ & $\begin{array}{l}\text { Early treatment } \\
\text { did not } \\
\text { significantly } \\
\text { reduce the risk of } \\
\text { GDM except in } \\
\text { non-obese } \\
\text { women }\end{array}$ \\
\hline
\end{tabular}

(Continued) 
Table I (Continued).

\begin{tabular}{|c|c|c|c|c|c|c|c|}
\hline $\begin{array}{l}\text { Author, } \\
\text { Year/Country } \\
\text { (Ref.) }\end{array}$ & Design & $\begin{array}{l}\text { Subjects } \\
\text { (N) }\end{array}$ & $\begin{array}{l}\text { Study } \\
\text { Population }\end{array}$ & $\begin{array}{l}\text { Timeframe } \\
\text { Early Testing } \\
\text { (Weeks) }\end{array}$ & $\begin{array}{l}\text { GDM Diagnosis } \\
\text { Criteria }\end{array}$ & Comparison & Main Results \\
\hline $\begin{array}{l}\text { Hughes, } 2018 \\
\text { (ongoing)/New } \\
\text { Zealand }^{24}\end{array}$ & RCT & 47 & $\begin{array}{l}\text { Women with } \\
\text { singleton } \\
\text { pregnancy } \\
\text { without ODIP, } \\
\text { with HbAIc } \\
\geq 5.9-6.4 \%\end{array}$ & $<14.0$ weeks & $\begin{array}{l}\text { 2h } 75 \text { h OGTT/ } \\
\text { New-Zealand } \\
\text { criteria }\end{array}$ & $\begin{array}{l}\text { Standard care vs } \\
\text { early } \\
\text { intervention in } \\
\text { pregnancies } \\
\text { complicated by } \\
\text { prediabetes }\end{array}$ & $\begin{array}{l}\text { First results } \\
\text { expected in } 2021\end{array}$ \\
\hline $\begin{array}{l}\text { Simmons, } 2018 \\
\text { (ToBOGM pilot } \\
\text { study)/ } \\
\text { Australia }^{25}\end{array}$ & $\mathrm{RCT}$ & 79 & $\begin{array}{l}\text { High risk } \\
\text { women with } \\
\text { singleton } \\
\text { pregnancy }\end{array}$ & $\begin{array}{l}<20.0 \text { weeks } \\
(4-19.6 \text { weeks })\end{array}$ & $\begin{array}{l}\text { 2h } 75 \mathrm{~g} \text { OGTT/ } \\
\text { IADPSG criteria }\end{array}$ & $\begin{array}{l}\text { Women with } \\
\text { booking GDM } \\
\text { receiving } \\
\text { immediate } \\
\text { (clinical referral } \\
\text { or ongoing } \\
\text { treatment) vs } \\
\text { deferred (no) } \\
\text { treatment vs } \\
\text { women without } \\
\text { booking GDM } \\
\text { ('decoys') }\end{array}$ & $\begin{array}{l}\text { More NICU } \\
\text { admission in the } \\
\text { early GDM group } \\
\text { with a tendency } \\
\text { for more SGA but } \\
\text { less LGA }\end{array}$ \\
\hline $\begin{array}{l}\text { Simmons, } 2018 \\
\text { (ToBOGM } \\
\text { study protocol)/ } \\
\text { International }^{28}\end{array}$ & $\mathrm{RCT}$ & 4000 & $\begin{array}{l}\text { High-risk } \\
\text { women with } \\
\text { singleton } \\
\text { pregnancy }\end{array}$ & $\begin{array}{l}<20.0 \text { weeks } \\
(4-19.6 \text { weeks })\end{array}$ & $\begin{array}{l}\text { 2h } 75 \mathrm{~g} \text { OGTT at } \\
24-28 \text { weeks/ } \\
2014 \text { ADIPS } \\
\text { criteria }\end{array}$ & $\begin{array}{l}\text { Intervention } \\
\text { (immediate } \\
\text { treatment) vs } \\
\text { control (no } \\
\text { treatment) vs } \\
\text { decoys (NGT } \\
\text { but undergo all } \\
\text { procedures) vs } \\
\text { non-active (NGT } \\
\text { and records } \\
\text { reviewed } \\
\text { postnatal) }\end{array}$ & $\begin{array}{l}\text { First results } \\
\text { expected mid- } \\
2021\end{array}$ \\
\hline $\begin{array}{l}\text { Vinter, 2018/ } \\
\text { Denmark }\end{array}$ & RCT & 90 & $\begin{array}{l}\text { Obese } \\
\text { pregnant } \\
\text { women (BMI } \\
\left.30-45 \mathrm{~kg} / \mathrm{m}^{2}\right) \\
\text { with singleton } \\
\text { pregnancy }\end{array}$ & $12-15$ weeks & $\begin{array}{l}\text { 2h } 75 \text { g OGTT/ } \\
\text { IADPSG Criteria }\end{array}$ & $\begin{array}{l}\text { Lifestyle } \\
\text { intervention vs } \\
\text { standard care }\end{array}$ & $\begin{array}{l}\text { Lifestyle } \\
\text { intervention was } \\
\text { not effective in } \\
\text { improving } \\
\text { obstetric or } \\
\text { metabolic } \\
\text { outcomes }\end{array}$ \\
\hline $\begin{array}{l}\text { Roeder, 2019/ } \\
\text { US }^{31}\end{array}$ & RCT & 157 & $\begin{array}{l}\text { Women with } \\
\text { hyperglycemia } \\
\text { (HbAlc } 5.7- \\
6.4 \% \text { and/or } \\
\text { FPG } 5.1-6.9 \\
\text { mmol/L) and } \\
\text { a singleton } \\
\text { pregnancy } \\
\text { without ODIP }\end{array}$ & $\leq 15.0$ weeks & $\begin{array}{l}2 \mathrm{~h} 75 \mathrm{~g} \text { OGTT at } \\
24-28 \text { weeks/ } \\
\text { IADPSG criteria }\end{array}$ & $\begin{array}{l}\text { Early pregnancy } \\
\text { vs } 3 \text { rd trimester } \\
\text { treatment of } \\
\text { hyperglycemia }\end{array}$ & $\begin{array}{l}\text { Treatment in early } \\
\text { pregnancy did not } \\
\text { improve maternal } \\
\text { or neonatal } \\
\text { outcomes } \\
\text { significantly }\end{array}$ \\
\hline
\end{tabular}

(Continued) 
Table I (Continued).

\begin{tabular}{|c|c|c|c|c|c|c|c|}
\hline $\begin{array}{l}\text { Author, } \\
\text { Year/Country } \\
\text { (Ref.) }\end{array}$ & Design & $\begin{array}{l}\text { Subjects } \\
\text { (N) }\end{array}$ & $\begin{array}{l}\text { Study } \\
\text { Population }\end{array}$ & $\begin{array}{l}\text { Timeframe } \\
\text { Early Testing } \\
\text { (Weeks) }\end{array}$ & $\begin{array}{l}\text { GDM Diagnosis } \\
\text { Criteria }\end{array}$ & Comparison & Main Results \\
\hline $\begin{array}{l}\text { Harper, 2020/ } \\
\text { US }^{29}\end{array}$ & RCT & 922 & $\begin{array}{l}\text { Obese women } \\
(\mathrm{BMI} \geq 30 \mathrm{~kg} / \\
\left.\mathrm{m}^{2}\right) \text { without } \\
\text { ODIP and } \\
\text { history of } \\
\text { bariatric } \\
\text { surgery }\end{array}$ & 14-20 weeks & $\begin{array}{l}\text { Two-step method: } \\
\text { Ih } 50 \mathrm{~g} \text { GCT } \\
\text { followed by a } 3 \mathrm{~h} \\
100 \mathrm{~g} \text { OGTT/CC } \\
\text { criteria }\end{array}$ & $\begin{array}{l}\text { Early GDM } \\
\text { screening (14-20 } \\
\text { weeks) vs } \\
\text { routine screening } \\
\text { ( } 24-28 \text { weeks) }\end{array}$ & $\begin{array}{l}\text { Early GDM } \\
\text { screening in obese } \\
\text { women did not } \\
\text { reduce the } \\
\text { composite } \\
\text { perinatal } \\
\text { outcomes, such as } \\
\text { macrosomia, } \\
\text { C-section and } \\
\text { shoulder dystocia }\end{array}$ \\
\hline $\begin{array}{l}\text { NCT03523 I } 43 \\
\text { (TESGO study) } \\
\text { (ongoing)/ } \\
\text { Taiwan }^{26}\end{array}$ & $\mathrm{RCT}$ & 2068 & $\begin{array}{l}\text { Singleton } \\
\text { pregnancy } \\
\text { without ODIP }\end{array}$ & 18-20 weeks & $\begin{array}{l}\text { 2h 75g OGTT/ } \\
\text { IADPSG criteria }\end{array}$ & $\begin{array}{l}\text { Early screening } \\
\text { group ( } 18-20 \\
\text { weeks) vs } \\
\text { standard } \\
\text { screening group } \\
\text { ( } 24-28 \text { weeks) }\end{array}$ & $\begin{array}{l}\text { Results expected } \\
\text { beginning of } 2021\end{array}$ \\
\hline
\end{tabular}

Abbreviations: GDM, gestational diabetes mellitus; GCT, glucose challenge test; OGTT, oral glucose tolerance test; FTFPG, first trimester fasting plasma glucose; CC, Carpenter and Coustan; FPG, fasting plasma glucose; RPG, random plasma glucose; WHO, World Health Organization; ADIPS, Australasian Siabetes in Pregnancy Society; $\mathrm{MOH}$, Ministry of Health; HbAlc, hemoglobin AIC; ACOG, American Congress of Obstetricians and Gynecologists; LGA, large-for-gestational age; C-section, caesarian section; NDDG, National Diabetes Data Group; ODIP, overt diabetes in pregnancy; IADPSG, International Association of the Diabetes and Pregnancy Study Groups; SIGN, Scottish Intercollegiate Guidelines Network; NGT, normal glucose tolerance; EGDM, early-onset gestational diabetes; LGDM, late-onset gestational diabetes; NICU, neonatal intensive care unit; RCT, randomized controlled trial; BG, blood glucose; SGA, small-for-gestational age; BMI, body mass index; TESGO, The Effect of Early Screening and Intervention for Gestational Diabetes Mellitus on Pregnancy Outcomes.

hypoglycemia and macrosomia; $41.2 \%$ vs $30.3 \%$, adjusted OR (aOR) 0.62, 95\% CI 0.43-0.91] in high-risk pregnant women. ${ }^{18}$ More recently, a large French study reported that women with early fasting hyperglycemia who received initial care versus those who did not, were more likely to be insulin-treated during pregnancy $(58.0 \%$ vs $20.9 \%$, respectively; $\mathrm{p}<0.00001$ ), gained less gestational weight $(8.6 \pm 5.4 \mathrm{~kg}$ vs $10.8 \pm 6.1 \mathrm{~kg}$, respectively; $\mathrm{p}<$ $0.00001)$, had a lower rate of preeclampsia $[1.2 \%$ vs $2.6 \%$, aOR $0.247(0.082-0.759), \mathrm{p}=0.01]$, and similar rates of LGA infants and shoulder dystocia. ${ }^{15}$ On the contrary, no beneficial effect of early diagnosing or treatment of GDM on maternal or neonatal outcomes was found in several other studies. ${ }^{19-22}$ These studies showed that early screening for GDM nearly doubled the prevalence of GDM and that women with an early GDM diagnosis were treated to a greater extent with pharmacotherapy. However, no differences were observed in neonatal outcomes such as small-for-gestational age (SGA) and LGA infants, cesarean sections and macrosomia. ${ }^{19,20}$ Hong et al reported that women who were screened prior to 20 weeks were more likely to receive insulin and to deliver preterm compared with routinely screened women. ${ }^{21}$ They hypothesized that early screening and diagnosis of GDM could result in more aggressive management of the disease due to a presumption of pregestational diabetes. Another prospective cohort study showed that early-onset GDM was associated with an increased risk of Apgar score at $1 \mathrm{~min}<7$, neonatal respiratory distress syndrome and neonatal intensive care unit (NICU) admission compared to the lateonset group. $^{22}$ In addition, the DALI (vitamin D And Lifestyle Intervention for GDM prevention) study in obese women showed that women with early GDM had a profile similar to the metabolic syndrome and that prepregnancy body mass index (BMI) was a strong predictor of early GDM. ${ }^{23}$ These findings support the need for weight control before pregnancy to improve perinatal outcomes.

Few results are yet available from large RCTs comparing treatment of early-onset GDM with standard treatment of GDM between 24 and 28 weeks of pregnancy (Table 1). Several large RCTs are still ongoing, such as the "Prediabetes in pregnancy, can early intervention improve outcomes" (PINTO) study, ${ }^{24}$ the "Treatment of Booking Gestational diabetes Mellitus" (ToBOGM) study ${ }^{25}$ and the "Effect of Early Screening and Intervention for Gestational 
Diabetes Mellitus on Pregnancy Outcomes" (TESGO) study (NCT03523143). ${ }^{26}$ A small RCT demonstrated that early treatment of mild hyperglycemia (HbAlc of 5.7$6.4 \%$ ) did not reduce the risk of GDM, except in nonobese women. ${ }^{27}$ A pilot study of the ToBOGM trial showed that early GDM treatment was associated with a reduced LGA rate $(0 \%$ vs $33 \% \mathrm{p}=0.030)$ but an increased NICU admission rate ( $36 \%$ vs $0 \% \mathrm{p}=0.043)$, largely driven by a higher rate of SGA infants. ${ }^{28}$ SGA can be a consequence of overtreatment or insufficient gestational weight gain. Other smaller RCTs did not show benefits of early screening and treatment of GDM on pregnancy outcomes. The EGGO study, for instance, showed no effect of early screening for GDM on the composite perinatal outcome consisting of macrosomia, primary cesarean delivery, hypertensive disease of pregnancy, shoulder dystocia, neonatal hyperbilirubinemia, and neonatal hypoglycemia in obese women. ${ }^{29}$ The LiP study evaluated the impact of lifestyle intervention vs standard care on metabolic and clinical outcomes in obese women with GDM in early pregnancy, classified according to the IADPSG criteria. They found no differences in obstetric or metabolic outcomes except for a higher rate of planned cesarean sections in the early treated group $(22.2 \%$ vs $5.6 \%, \mathrm{p}=0.02) .{ }^{30}$ In addition, an RCT in 200 women with hyperglycemia in early pregnancy showed that early treatment could not improve maternal or neonatal outcomes significantly. ${ }^{31}$

Different methods have been suggested for the screening of GDM in early pregnancy: direct glycemic markers such as FPG, indirect methods like HbAlc, and more recently biochemical markers (Table 1). Riskin et al demonstrated that higher first-trimester FPG levels in the non-diabetic range increased the risk for adverse pregnancy outcomes, including cesarean sections, LGA infants and macrosomia. ${ }^{32}$ Likewise, a multicentric Belgian prospective cohort study showed recently that women with a FPG of $5.1-5.5 \mathrm{mmol} / \mathrm{L}$ in early pregnancy had a significantly higher NICU admission rate compared to women with FPG $<5.1 \mathrm{mmol} / \mathrm{L}(20.4 \%$ vs $9.3 \%$, p = 0.009). ${ }^{33}$ On the contrary, several studies have shown that a $\mathrm{FPG} \geq 5.1 \mathrm{mmol} / \mathrm{L}$ in early pregnancy was a poor predictor of GDM. ${ }^{15,33}$ A Belgian study demonstrated that only $37 \%$ of all women with an $\mathrm{FPG} \geq 5.1-5.5 \mathrm{mmol} / \mathrm{L}$ in early pregnancy developed GDM based on the IADPSG criteria later in pregnancy. ${ }^{33} \mathrm{~A}$ large Chinese study showed that in their population an FPG $6.1-7.0 \mathrm{mmol} / \mathrm{L}$ in early pregnancy was a much stronger predictor for GDM later in pregnancy compared to an $\mathrm{FPG} \geq 5.1 \mathrm{mmol} / \mathrm{L} .{ }^{34}$ A French study recommended to use a threshold of $5.5 \mathrm{mmol} / \mathrm{L}$ for starting GDM treatment in early pregnancy, as they demonstrated improved pregnancy outcomes in these women. ${ }^{15}$

Few studies evaluated the use of HbAlc in early pregnancy to diagnose GDM. ${ }^{35-39}$ It has been established that an early $\mathrm{HbAlc} \geq 5.9 \%$ identified women at high risk of adverse pregnancy outcomes independently of GDM diagnosis later in pregnancy. ${ }^{35,39} \mathrm{HbA} 1 \mathrm{c}$ can be used to screen for overt diabetes, but most studies demonstrated that $\mathrm{HbAlc}$ in early pregnancy has insufficient sensitivity and specificity to use as a diagnostic test for GDM. However, it could still be useful in simplifying the algorithm for GDM screening. ${ }^{36-38}$ A retrospective cohort study showed that $\mathrm{HbAlc}$ at first prenatal visit allowed an early diagnosis of GDM in $25.8 \%$ of women; however, HbAlc could not replace routine testing for GDM later in pregnancy with an OGTT because of poor sensitivity. ${ }^{37} \mathrm{HbAlc}$ could be used as an adjunct to routine testing, identifying those with values between $5.9 \%$ and $6.4 \%$ at high risk of GDM early in pregnancy, allowing early intervention to potentially improve perinatal outcomes. However, RCTs are needed to prove that treatment of women with mildly elevated $\mathrm{HbA} 1 \mathrm{c}$ in early pregnancy leads to better outcomes.

\section{Prediction Models in Early Pregnancy}

Improved prediction of GDM through identification of risk factors might increase the diagnostic accuracy of selective screening strategies and allow lifestyle interventions in early pregnancy to prevent the development of GDM and adverse pregnancy outcomes. Various risk factors for GDM have been identified, but it remains a struggle to accurately predict who is at increased risk to develop GDM. Several studies have proposed prediction models, such as the risk scores of van Leeuwen en Teede ${ }^{40,41}$ (Table 1). More recently, Benhalima et al developed a prediction model for GDM based on the IADPSG criteria, using easy available clinical and biochemical risk factors in early pregnancy ${ }^{42}$ In this model, a history of a first degree relative with diabetes, a history of GDM, non-Caucasian origin, age, height, weight, FPG, triglycerides and $\mathrm{HbAlc}$ were independent predictors for GDM, with an area under the curve (AUC) of the model of 0.72 [95\% confidence interval (CI) $0.66-0.78]$ after crossvalidation, compared to an AUC of 0.67 (95\% CI $0.63-$ 0.71) using the van Leeuwen model and an AUC of 0.66 
(95\% CI 0.62-0.70) using the Teede model. ${ }^{40-42}$ In conclusion, prediction models based on variables in early pregnancy seem to have moderate accuracy to predict GDM.

\section{Screening for GDM Between 24 and 28 Weeks of Pregnancy} Introduction of the IAPDSG Criteria: What is the Impact on Prevalence and Outcomes?

Since 2010, the IADPSG recommends a universal one-step approach with a 75g OGTT at 24-28 weeks of pregnancy for screening and diagnosis of GDM. The IADPSG criteria have been adopted by the WHO since 2013, and are therefore now commonly referred to as the 2013 WHO criteria for GDM. ${ }^{2,11}$ However, the IADPSG recommendation remains controversial due to the significant increase in GDM prevalence. Moreover, the implementation of the IADPSG screening strategy leads to an increased workload with the need for a fasting test, and this might lead to increased medicalization of care. An overview of the most commonly used guidelines for screening and diagnosis of GDM is shown in Table 2.

Many studies reported a substantial increase in the prevalence of GDM if the more stringent IADPSG criteria are adopted. $^{43-49}$ However, conflicting evidence exists regarding the impact of introducing IADPSG criteria on maternal and neonatal outcomes. There are no RCTs that have compared treatment of GDM based on the IADPSG criteria with no treatment. Some observational studies reported no difference or even an increase in adverse perinatal outcomes, ${ }^{46,47,50-55}$ whereas others showed a significant improvement in perinatal outcomes associated with the use of the IADPSG criteria ${ }^{56-58}$ (Table 3).

A Spanish study reported that the prevalence of GDM doubled following the introduction of the IADPSG screening strategy compared to the previous use of the two-step screening strategy with the Carpenter and Coustan criteria (CC). The adoption of the IADPSG criteria improved pregnancy outcomes such as a reduction in the rate of gestational hypertension $(4.1$ to $3.5 \% ;-14.6 \%$, p <

Table 2 Current Guidelines for Screening and Diagnosis of GDM

\begin{tabular}{|c|c|c|c|c|c|c|c|}
\hline $\begin{array}{l}\text { Guideline, } \\
\text { Year }\end{array}$ & Range & $\begin{array}{l}\text { One- } \\
\text { Step }\end{array}$ & $\begin{array}{l}\text { Two- } \\
\text { Step }\end{array}$ & OGTT Criteria & $\begin{array}{l}\text { OGTT } \\
\text { Time }\end{array}$ & $\begin{array}{l}\text { Risk } \\
\text { Factors } \\
\text { List }\end{array}$ & Screening in Early Pregnancy \\
\hline IADPSG, 2010 & Global & $\sqrt{ }$ & & $\begin{array}{l}\geq 5.1 \text { (fasting), } \\
\geq 10.0 \text { ( I h) and/or } \\
\geq 8.5 \mathrm{mmol} / \mathrm{L}(2 \mathrm{~h})\end{array}$ & 24-28 weeks & $\sqrt{ }$ & $\begin{array}{l}\mathrm{FPG} \geq 5.1 \mathrm{mmol} / \mathrm{L} \text { in early pregnancy is diagnosed } \\
\text { as GDM }\end{array}$ \\
\hline WHO, 2013 & Global & $\sqrt{ }$ & & IADPSG & Any time & & $\begin{array}{l}\text { Criteria apply for the diagnosis of GDM at any } \\
\text { time during pregnancy }\end{array}$ \\
\hline FIGO, 2015 & Global & $\sqrt{ }$ & & IADPSG & $\begin{array}{l}24-28 \text { weeks } \\
\text { or any other } \\
\text { time }\end{array}$ & $\sqrt{ }$ & Not applicable due to lack of clear evidence \\
\hline NICE, 2015 & UK & $\sqrt{ }$ & & $\begin{array}{l}\geq 5.6 \mathrm{mmol} / \mathrm{L} \\
\text { (fasting) or } \geq 7.8 \\
\mathrm{mmol} / \mathrm{L}(2 \mathrm{~h})\end{array}$ & 24-28 weeks & $\sqrt{ }$ & $\begin{array}{l}75 \mathrm{~g} 2 \mathrm{~h} \text { OGTT in women with previous GDM as } \\
\text { soon as possible after booking }\end{array}$ \\
\hline ACOG, 2018 & US & & $\sqrt{ }$ & CC/NDDG & 24-28 weeks & $\sqrt{ }$ & $\begin{array}{l}\text { Consider testing in all women with BMI }>25 \mathrm{~kg} / \\
\mathrm{m}^{2} \text { (or }>23 \mathrm{~kg} / \mathrm{m}^{2} \text { in Asian Americans) and with } \\
\geq \mathrm{I} \text { additional risk factors }\end{array}$ \\
\hline ADA, 202I & US & $\sqrt{ }$ & $\sqrt{ }$ & IADPSG/CC & 24-28 weeks & $\sqrt{ }$ & $\begin{array}{l}\text { OGTT for high-risk women at the first antenatal } \\
\text { visit and classified as TIDM or T2DM }\end{array}$ \\
\hline
\end{tabular}

Notes: The OGTT threshold value of IADPSG criteria is $5.1-10.0-8.5 \mathrm{mmol} / \mathrm{L}$ for a $2 \mathrm{~h} 75 \mathrm{~g}$ OGTT. One or more of these threshold values must be equaled or exceeded for the diagnosis of GDM. The OGTT threshold value of CC criteria is 5.3-10.0-8.6-7.8 mmol/L for a $3 \mathrm{~h} 100 \mathrm{~g}$ OGTT. The OGTT threshold value of NDDG criteria is 5.810.6-9.2-8.0 mmol/L for a $4 \mathrm{~h} 100 \mathrm{~g}$ OGTT. For CC and NDDG criteria, a diagnosis generally requires that two or more thresholds be met or exceeded, although some clinicians choose to use just one elevated value.

Abbreviations: GDM, gestational diabetes mellitus; OGTT, oral glucose tolerance test; IADPSG, International Association of Diabetic Pregnancy Study Group; FPG, fasting plasma glucose; WHO, World Health Organization; FIGO, International Federation of Gynecology and Obstetrics; NICE, National Institute for Health and Care Excellence; ACOG, American Congress of Obstetricians and Gynecologists; CC, Carpenter and Coustan; NDDG, National Diabetes Data Group; BMI, body mass index; ADA, American Diabetes Association; TIDM, Type I diabetes mellitus; T2DM, type 2 diabetes mellitus. 
Table 3 One-Step Screening with IADPSG Criteria versus One- or Two-Step Screening with Other Criteria

\begin{tabular}{|c|c|c|c|c|c|}
\hline $\begin{array}{l}\text { Author, } \\
\text { Yearl } \\
\text { Country } \\
\text { (Ref.) }\end{array}$ & Design & $\begin{array}{l}\text { Subjects } \\
\text { (N) }\end{array}$ & Study Population & Comparison & Main Results \\
\hline \multicolumn{6}{|c|}{ Observational Studies } \\
\hline $\begin{array}{l}\text { Agarwal, 2010/ } \\
\text { UAE }^{45}\end{array}$ & $\begin{array}{l}\text { Retrospective } \\
\text { cohort study }\end{array}$ & 10,283 & All pregnant women & $\begin{array}{l}\text { Impact of IADPSG criteria on } \\
\text { GDM diagnosis compared to ADA } \\
\text { criteria }\end{array}$ & $\begin{array}{l}\text { The IADPSG criteria caused } \\
\text { a } 2.9 \text {-fold increase in GDM } \\
\text { prevalence ( } 37.7 \% \text { of all pregnant } \\
\text { women with IADPSG criteria vs } \\
\text { I2.9\% with ADA criteria) }\end{array}$ \\
\hline $\begin{array}{l}\text { Rajput, 2012/ } \\
\text { India }^{49}\end{array}$ & $\begin{array}{l}\text { Prospective } \\
\text { study }\end{array}$ & 607 & $\begin{array}{l}\text { Pregnant women } \\
\text { without ODIP }\end{array}$ & $\begin{array}{l}\text { HbAlc in combination with ADA } \\
\text { vs IADPSG criteria for diagnosis of } \\
\text { GDM }\end{array}$ & $\begin{array}{l}7.1 \% \text { were diagnosed as having } \\
\text { GDM based on ADA criteria while } \\
23.72 \% \text { women were diagnosed as } \\
\text { having GDM using IADPSG criteria }\end{array}$ \\
\hline $\begin{array}{l}\text { Benhalima, } \\
2013 / \\
\text { Belgium }^{59}\end{array}$ & $\begin{array}{l}\text { Retrospective } \\
\text { cohort study }\end{array}$ & 6727 & $\begin{array}{l}\text { Singleton } \\
\text { pregnancies without } \\
\text { ODIP and bariatric } \\
\text { surgery }\end{array}$ & $\begin{array}{l}\text { CC criteria (old GDM) vs IADPSG } \\
\text { criteria (new GDM) for GDM } \\
\text { screening }\end{array}$ & $\begin{array}{l}\text { More women were identified as } \\
\text { having GDM using the IADPSG } \\
\text { criteria and these women carried } \\
\text { an increased risk for adverse } \\
\text { gestational outcome compared to } \\
\text { women without GDM }\end{array}$ \\
\hline $\begin{array}{l}\text { Duran, 2014/ } \\
\text { Spain }^{56}\end{array}$ & $\begin{array}{l}\text { Prospective } \\
\text { cohort study }\end{array}$ & 3276 & $\begin{array}{l}\text { Pregnant women } \\
\text { without ODIP }\end{array}$ & $\begin{array}{l}\text { One-step IADPSG vs two-step } \\
\text { ADA recommended GDM } \\
\text { screening }\end{array}$ & $\begin{array}{l}\text { Application of IADPSG screening } \\
\text { was associated with a } 3.5 \text {-fold } \\
\text { increase in GDM prevalence as } \\
\text { well as significant improvements in } \\
\text { pregnancy outcomes }\end{array}$ \\
\hline $\begin{array}{l}\text { Fuller, 20I4/ } \\
\text { US }^{50}\end{array}$ & $\begin{array}{l}\text { Pre-post } \\
\text { comparison } \\
\text { study }\end{array}$ & 812 & $\begin{array}{l}\text { Pregnant women } \\
\text { without ODIP and } \\
\text { gastric bypass }\end{array}$ & $\begin{array}{l}\text { One-step ( } 2 \mathrm{~h} 75 \mathrm{~g} \text { OGTT, IADPSG } \\
\text { criteria) vs two-step }(50 \mathrm{~g} \mathrm{GCT} \\
\text { followed by } 3 \mathrm{~h} 100 \mathrm{~g} \text { OGTT and } \\
\mathrm{CC} \text { criteria if GCT } \geq 7.5 \mathrm{mmol} / \mathrm{L})\end{array}$ & $\begin{array}{l}\text { Despite a } 4.7 \% \text { increase in GDM } \\
\text { (from } 7 \% \text { to II.7\%), no differences in } \\
\text { delivery or neonatal outcomes and } \\
\text { no lower rates of compliance with } \\
\text { screening were found when using } \\
\text { one-step vs two-step screening }\end{array}$ \\
\hline $\begin{array}{l}\text { Hung, 20I5/ } \\
\text { Taiwan }^{58}\end{array}$ & $\begin{array}{l}\text { Before-after } \\
\text { retrospective } \\
\text { cohort study }\end{array}$ & 6697 & $\begin{array}{l}\text { Singleton } \\
\text { pregnancies }>24 \\
\text { weeks without } \\
\text { ODIP }\end{array}$ & $\begin{array}{l}\text { One-step IADPSG screening (P2) } \\
\text { vs two-step screening (50g GCT } \\
\text { followed by 100g } 3 \mathrm{~h} \text { OGTT with } \\
\text { CC criteria if the GCT } \geq 7.8 \mathrm{mmol} / \\
\text { L) (PI) }\end{array}$ & $\begin{array}{l}\text { GDM incidence increased from } \\
4.6 \% \text { in PI to } 12.4 \% \text { in P2. } \\
\text { Adoption of the IADPSG criteria } \\
\text { led to a significant reduction in } \\
\text { maternal weight gain during } \\
\text { pregnancy, birth weight, and the } \\
\text { rates of macrosomia and LGA }\end{array}$ \\
\hline $\begin{array}{l}\text { Meek, 2015/ } \\
\text { UK }^{60}\end{array}$ & $\begin{array}{l}\text { Retrospective } \\
\text { study }\end{array}$ & 25,543 & $\begin{array}{l}\text { Singleton } \\
\text { pregnancies without } \\
\text { ODIP }\end{array}$ & $\begin{array}{l}\text { One-step IADPSG criteria vs one- } \\
\text { step NICE } 2015 \text { criteria for GDM } \\
\text { screening }\end{array}$ & $\begin{array}{l}\text { The IADPSG criteria identified } \\
\text { women at substantial risk of } \\
\text { complications such as LGA who } \\
\text { would not be identified by the } \\
\text { NICE } 2015 \text { criteria }\end{array}$ \\
\hline $\begin{array}{l}\text { Feldman, } \\
2016 / \text { US }^{52}\end{array}$ & $\begin{array}{l}\text { Before-after } \\
\text { retrospective } \\
\text { cohort study }\end{array}$ & 6066 & $\begin{array}{l}\text { Singleton } \\
\text { pregnancies without } \\
\text { ODIP }\end{array}$ & $\begin{array}{l}\text { One-step (IADPSG criteria) vs } \\
\text { two-step GDM screening (CC } \\
\text { criteria) }\end{array}$ & $\begin{array}{l}\text { The IADPSG screening method } \\
\text { was associated with a higher rate } \\
\text { of GDM ( } 27 \% \text { vs } 17 \% \text { ) but not with } \\
\text { a reduction in LGA newborns or } \\
\text { cesarean deliveries }\end{array}$ \\
\hline
\end{tabular}

(Continued) 
Table 3 (Continued).

\begin{tabular}{|c|c|c|c|c|c|}
\hline $\begin{array}{l}\text { Author, } \\
\text { Yearl } \\
\text { Country } \\
\text { (Ref.) }\end{array}$ & Design & $\begin{array}{l}\text { Subjects } \\
\text { (N) }\end{array}$ & Study Population & Comparison & Main Results \\
\hline $\begin{array}{l}\text { March, 2016/ } \\
\text { US }^{53}\end{array}$ & $\begin{array}{l}\text { Retrospective } \\
\text { cohort study }\end{array}$ & 235 & $\begin{array}{l}\text { Singleton } \\
\text { pregnancies }\end{array}$ & $\begin{array}{l}\text { One-step (IADPSG) vs two-step } \\
\text { (NDDG criteria) GDM screening }\end{array}$ & $\begin{array}{l}\text { The one-step method identified } \\
\text { women with at least equally high } \\
\text { risk of adverse outcomes as the } \\
\text { two-step method }\end{array}$ \\
\hline $\begin{array}{l}\text { Waters, 2016/ } \\
\text { North } \\
\text { America }^{48}\end{array}$ & $\begin{array}{l}\text { Secondary } \\
\text { analysis of } \\
\text { prospectively } \\
\text { collected data }\end{array}$ & 6159 & $\begin{array}{l}\text { Singleton } \\
\text { pregnancies without } \\
\text { ODIP and fertility } \\
\text { treatment }\end{array}$ & $\begin{array}{l}\text { GDM based on CC criteria (also } \\
\text { GDM based on IADPSG criteria) } \\
\text { vs GDM diagnosed with IADPSG } \\
\text { criteria but not CC criteria vs no } \\
\text { GDM }\end{array}$ & $\begin{array}{l}\text { Women diagnosed with GDM } \\
\text { based on IADPSG criteria had } \\
\text { higher adverse outcome } \\
\text { frequencies compared with women } \\
\text { without GDM }\end{array}$ \\
\hline $\begin{array}{l}\text { Huhn, 20I7/ } \\
\text { Switzerland }\end{array}$ & $\begin{array}{l}\text { Retrospective } \\
\text { cohort study }\end{array}$ & $\begin{array}{l}\text { I } 367 \\
\text { allocated }\end{array}$ & $\begin{array}{l}\text { Women with } \\
\text { singleton pregnancy } \\
\text { and without ODIP }\end{array}$ & $\begin{array}{l}\text { Two-step screening with } 50 \mathrm{~g} \text { GCT } \\
\text { and } 2 \mathrm{~h} 75 \mathrm{~g} \text { OGTT (period I) vs } \\
\text { one-step } 75 \mathrm{~g} \text { OGTT with IADPSG } \\
\text { criteria (period } 2 \text { ) }\end{array}$ & $\begin{array}{l}\text { Introduction of the IADPSG criteria } \\
\text { resulted in an absolute increase of } \\
\text { GDM prevalence of } 8.5 \% \text { ( } 3.3 \% \text { in } \\
\text { period I to } 11.8 \% \text { in period } 2 \text { ) }\end{array}$ \\
\hline $\begin{array}{l}\text { Adam, 20I7/ } \\
\text { South Africa }\end{array}$ & $\begin{array}{l}\text { Prospective } \\
\text { cohort study }\end{array}$ & 554 & $\begin{array}{l}\text { All pregnant women } \\
<26 \text { weeks }\end{array}$ & $\begin{array}{l}\text { IADPSG vs NICE vs WHO I } 999 \text { vs } \\
\text { Western Cape criteria using } \\
\text { universal or selective screening }\end{array}$ & $\begin{array}{l}\text { Substantial increase in prevalence } \\
\text { of GDM with use of the IADPSG } \\
\text { criteria, regardless of universal or } \\
\text { selective screening }\end{array}$ \\
\hline $\begin{array}{l}\text { Luewan, 2018/ } \\
\text { Thailand }^{46}\end{array}$ & $\begin{array}{l}\text { Prospective } \\
\text { descriptive } \\
\text { study }\end{array}$ & 648 & $\begin{array}{l}\text { Singleton } \\
\text { pregnancies } \\
\text { excluding those with } \\
\text { high risk for GDM }\end{array}$ & $\begin{array}{l}\text { One-step (IADPSG) vs two-step } \\
\text { GDM screening based on } \\
\text { preference }\end{array}$ & $\begin{array}{l}\text { Prevalence of GDM was } \\
\text { significantly higher in the one-step } \\
\text { group ( } 32.0 \% \text { vs } 10.3 \% \text { ) without } \\
\text { clear evidence of better outcomes }\end{array}$ \\
\hline $\begin{array}{l}\text { Goedegebure, } \\
2018 / \text { the } \\
\text { Netherlands }\end{array}$ & $\begin{array}{l}\text { Multicenter } \\
\text { retrospective } \\
\text { cohort study }\end{array}$ & 1386 & $\begin{array}{l}\text { Singleton } \\
\text { pregnancies without } \\
\text { ODIP }\end{array}$ & $\begin{array}{l}\text { WHO-20I3 (IADPSG) vs WHO- } \\
\text { I999 GDM criteria }\end{array}$ & $\begin{array}{l}\text { Using WHO-20 I } 3 \text { criteria resulted } \\
\text { in earlier GDM diagnosis, less need } \\
\text { for insulin treatment and more } \\
\text { spontaneous deliveries, but no } \\
\text { differences in adverse pregnancy } \\
\text { outcomes compared to WHO- } \\
1999 \text { criteria }\end{array}$ \\
\hline $\begin{array}{l}\text { Benhalima, } \\
2018 \\
\text { (Diabetes } \\
\text { Care)/ } \\
\text { Belgium }^{89}\end{array}$ & $\begin{array}{l}\text { Multicentric } \\
\text { prospective } \\
\text { cohort study }\end{array}$ & 2006 & $\begin{array}{l}\text { Singleton } \\
\text { pregnancies without } \\
\text { ODIP and history of } \\
\text { bariatric surgery }\end{array}$ & $\begin{array}{l}\text { Sensitivity and specificity of the } 50 \mathrm{~g} \\
\text { GCT in a universal two-step } \\
\text { screening strategy for GDM using } \\
\text { IADPSG criteria vs a universal one- } \\
\text { step screening with the } 75 \mathrm{~g} \text { OGTT } \\
\text { and IADPSG criteria }\end{array}$ & $\begin{array}{l}\text { The GCT has a moderate diagnostic } \\
\text { accuracy in a universal two-step } \\
\text { screening strategy with IADPSG } \\
\text { criteria; lowering the threshold for } \\
\text { the GCT from } 7.8 \text { to } 7.2 \mathrm{mmol} / \mathrm{L} \\
\text { would increase sensitivity from } 60 \% \\
\text { to } 72 \% \text { and more than } 60 \% \text { of all } \\
\text { OGTTs could be avoided }\end{array}$ \\
\hline $\begin{array}{l}\text { Pocobelli, } \\
2018 / \text { US }^{54}\end{array}$ & $\begin{array}{l}\text { Before-after } \\
\text { cohort study }\end{array}$ & 23,257 & $\begin{array}{l}\text { Singleton live birth } \\
\text { deliveries in women } \\
\text { without ODIP }\end{array}$ & $\begin{array}{l}\text { Two-step screening with } 50 \mathrm{~g} \mathrm{GCT} / \\
\text { FPG test followed by a } 3 \mathrm{~h} 100 \mathrm{~g} \\
\text { OGTT vs one-step IADPSG } \\
\text { screening }\end{array}$ & $\begin{array}{l}\text { Adopting the one-step approach } \\
\text { was associated with an increase in } \\
\text { GDM diagnosis (by } 41 \% \text { ), and in } \\
\text { rates of labor induction and } \\
\text { neonatal hypoglycemia, without } \\
\text { association with other outcomes } \\
\text { including cesarean delivery or } \\
\text { macrosomia }\end{array}$ \\
\hline
\end{tabular}

(Continued) 
Table 3 (Continued).

\begin{tabular}{|c|c|c|c|c|c|}
\hline $\begin{array}{l}\text { Author, } \\
\text { Yearl } \\
\text { Country } \\
\text { (Ref.) }\end{array}$ & Design & $\begin{array}{l}\text { Subjects } \\
\text { (N) }\end{array}$ & Study Population & Comparison & Main Results \\
\hline $\begin{array}{l}\text { Costa, 2019/ } \\
\text { Belgium }^{51}\end{array}$ & $\begin{array}{l}\text { Retrospective } \\
\text { cohort study }\end{array}$ & 6051 & $\begin{array}{l}\text { Singleton } \\
\text { pregnancies without } \\
\text { ODIP }\end{array}$ & $\begin{array}{l}\text { Two-step ( } 50 \mathrm{~g} \text { GCT and } 75 \mathrm{~g} \\
\text { OGTT if GCT } \geq 7.8 \mathrm{mmol} / \mathrm{L} \text {; CC } \\
\text { criteria) vs one-step screening } \\
\text { (IADPSG criteria) }\end{array}$ & $\begin{array}{l}\text { GDM prevalence increased from } \\
3.4 \% \text { to } 16.3 \% \text {, without having } \\
\text { a statistically significant impact on } \\
\text { pregnancy outcomes }\end{array}$ \\
\hline $\begin{array}{l}\text { Cade, } 2019 / \\
\text { Australia }^{57}\end{array}$ & $\begin{array}{l}\text { Quasi- } \\
\text { experimental } \\
\text { retrospective } \\
\text { study }\end{array}$ & 14,498 & $\begin{array}{l}\text { Singleton } \\
\text { pregnancies without } \\
\text { ODIP }\end{array}$ & $\begin{array}{l}\text { I99|/I998 ADIPS criteria vs } \\
\text { IADPSG criteria }\end{array}$ & $\begin{array}{l}\text { Adoption of IADPSG criteria } \\
\text { increased the incidence of GDM by } \\
74 \% \text { and the overall cost of care } \\
\text { without obvious changes in } \\
\text { immediate clinical outcomes }\end{array}$ \\
\hline $\begin{array}{l}\text { Meloncelli, } \\
2020 / \\
\text { Australia }^{47}\end{array}$ & $\begin{array}{l}\text { Pre-post } \\
\text { comparison } \\
\text { study }\end{array}$ & 124,117 & $\begin{array}{l}\text { All pregnant women } \\
\text { giving birth }>24 \\
\text { weeks }\end{array}$ & $\begin{array}{l}\text { Two-step process and I998 ADIPS } \\
\text { GDM diagnostic criteria (in 20I4) } \\
\text { vs one-step process and IADPSG } \\
\text { criteria (in 2016) }\end{array}$ & $\begin{array}{l}\text { GDM diagnosis increased from } \\
8.7 \% \text { to } 11.9 \% \text {, with no observed } \\
\text { changes to measured perinatal } \\
\text { outcomes, except for a very small } \\
\text { decrease in respiratory distress }\end{array}$ \\
\hline \multicolumn{6}{|l|}{ RCTs } \\
\hline $\begin{array}{l}\text { Mirzamoradi, } \\
2015 / \operatorname{Iran}^{61}\end{array}$ & $\mathrm{RCT}$ & 189 & $\begin{array}{l}\text { Singleton } \\
\text { pregnancies without } \\
\text { ODIP, with } \\
\text { a disturbed FPG or } \\
\text { blood sugar at the } \\
\text { OGTT }\end{array}$ & $\begin{array}{l}\text { Interventional (one-step screening } \\
\text { with IADPSG criteria) vs control } \\
\text { group (two-step GDM screening } \\
\text { according to ACOG } \\
\text { recommendation and CC/NDDG } \\
\text { criteria) }\end{array}$ & $\begin{array}{l}\text { Although the treatment of mild } \\
\text { GDM (IADPSG) could not } \\
\text { significantly decrease severe } \\
\text { gestational outcomes, it did } \\
\text { significantly reduce the risk of } \\
\text { hyperbilirubinemia (OR } 0.25 \text { ) and } \\
\text { its subsequent complications }\end{array}$ \\
\hline $\begin{array}{l}\text { Abebe, } 2017 \\
\text { (ongoing)/US }\end{array}$ & RCT & 921 & $\begin{array}{l}\text { Pregnant women } \\
\text { from } 18 \text { to } 28 \\
\text { weeks gestation }\end{array}$ & $\begin{array}{l}\text { 50g GCT for all participants, then } \\
\text { I:I randomization in } 75 \mathrm{~g} \text { (one- } \\
\text { step, IADPSG) or } 100 \mathrm{~g} \text { (two-step, } \\
\text { CC) OGTT }\end{array}$ & No results published yet \\
\hline $\begin{array}{l}\text { Satodiya, } \\
2017 / \text { India }^{62}\end{array}$ & RCT & 1000 & $\begin{array}{l}\text { Pregnant women } \\
\text { without ODIP }\end{array}$ & $\begin{array}{l}\text { Two-step screening (ACOG } \\
\text { recommendation, group A) vs one- } \\
\text { step screening (IADPSG criteria, } \\
\text { group B) }\end{array}$ & $\begin{array}{l}\text { Incidence of GDM using IADPSG } \\
\text { criteria was almost doubled (I I.8\% vs } \\
\text { 19.2\%), whereas maternal and fetal } \\
\text { outcomes were comparable, except } \\
\text { in } 15.8 \% \text { women diagnosed as GDM } \\
\text { and suffered from hypoglycemia }\end{array}$ \\
\hline $\begin{array}{l}\text { Fadl, } 2019 \\
\text { (ongoing)/ } \\
\text { Sweden }^{64}\end{array}$ & RCT & $\pm 65,000$ & $\begin{array}{l}\text { Pregnant women } \\
\text { without ODIP }\end{array}$ & $\begin{array}{l}\text { Intervention (WHO } 2013 \text { criteria) } \\
\text { vs control group (former Swedish } \\
\text { diagnostic criteria) }\end{array}$ & $\begin{array}{l}\text { No results published yet (expected } \\
\text { in 2020) }\end{array}$ \\
\hline $\begin{array}{l}\text { Hillier, 202I/ } \\
\text { US }^{63}\end{array}$ & RCT & 23,792 & $\begin{array}{l}\text { Singleton } \\
\text { pregnancies without } \\
\text { history of bariatric } \\
\text { surgery }\end{array}$ & $\begin{array}{l}\text { One-step ( } 2 \mathrm{~h} 75 \mathrm{~g} \text { OGTT according } \\
\text { to IADPSG criteria) vs two-step } \\
\text { GDM screening (I } \mathrm{h} 50 \mathrm{~g} \mathrm{GCT} \text { and } \\
\text { a } 3 \mathrm{~h} 100 \mathrm{~g} \text { OGTT according to CC } \\
\text { criteria) }\end{array}$ & $\begin{array}{l}\text { Despite more diagnoses of GDM } \\
\text { with the one-step approach ( } 16.5 \% \text { vs } \\
8.5 \%) \text {, there were no significant } \\
\text { differences in the risks of the primary } \\
\text { outcomes relating to perinatal and } \\
\text { maternal complications }\end{array}$ \\
\hline
\end{tabular}

Abbreviations: UAE, United Arab Emirates; IADPSG, International Association of the Diabetes and Pregnancy Study Groups; GDM, gestational diabetes mellitus; ADA, American Diabetes Association; ODIP, overt diabetes in pregnancy; HbAlc, hemoglobin AIC; CC, Carpenter and Coustan; OGTT, oral glucose tolerance test; GCT, glucose challenge test; LGA, large-for-gestational age; NICE, National Institute for Health and Care Excellence; NDDG, National Diabetes Data Group; WHO, World Health Organization; FPG, fasting plasma glucose; ADIPS, Australasian diabetes in pregnancy society; RCT, randomized controlled trial; ACOG, American Congress of Obstetricians and Gynecologists. 
0.021 ), cesarean section (25.4 to $19.7 \%$; $-23.9 \%$, p < 0.002 ), LGA rate ( 4.6 to $3.7 \% ;-20 \%, \mathrm{p}<0.004)$, SGA rate $(7.7$ to $7.1 \% ;-6.5 \%, \mathrm{p}<0.042)$, and NICU admissions $(8.2$ to $6.2 \% ;-24.4 \%, \mathrm{p}<0.001) .{ }^{56}$ In contrast, an Australian study showed a $74 \%$ increase in annual incidence of GDM by changing from the "Australasian Diabetes in Pregnancy Society" (ADIPS) diagnostic criteria to the universal IADPSG strategy. This was not associated with improvements in primary health outcomes such as caesarean section rates, hypertensive disorder of pregnancy, LGA infant rates and preterm birth. ${ }^{57}$ However, babies born to mothers with GDM diagnosed with the IADPSG criteria had lower rates of neonatal hypoglycemia and NICU admissions, suggesting a milder form of the disease. ${ }^{57} \mathrm{~A}$ Belgian retrospective cohort study reported that GDM prevalence increased significantly from $3.4 \%$ to $16.2 \%$ comparing a two-step screening strategy with one-step IADPSG criteria, but no significant differences in maternal and neonatal complications were observed. $^{51}$ A pre-post comparison study in Australia also found that the introduction of the IADPSG criteria increased GDM prevalence from $8.7 \%$ to $11.9 \%$, but that it was not associated with lower rates of gestational hypertension, cesarean birth, or LGA or SGA neonates. ${ }^{47}$ A multicenter retrospective study demonstrated that introducing the IADPSG criteria resulted in an earlier GDM diagnosis, lower rates of insulin treatment and more spontaneous deliveries compared with a cohort diagnosed with the 1999 WHO criteria. However, no significant differences were found in adverse pregnancy outcomes. ${ }^{55}$ Studies that evaluated perinatal outcomes of women diagnosed with GDM by the IADPSG criteria who would not have been identified with other criteria showed in general that these women had higher adverse outcome rates compared with GDM-negative controls. ${ }^{48,59,60}$

These conflicting results highlight the need for longterm, adequately powered, prospective research to establish if applying the IADPSG one-step screening strategy decreases the frequency of adverse outcomes. An overview of the (ongoing) RCTs is given in Table 3. A small Iranian RCT compared pregnancy outcomes in women diagnosed with GDM by the IADPSG one-step screening versus two-step screening using the $\mathrm{CC}$ criteria. They demonstrated that the group diagnosed with the IADPSG criteria had only a decreased risk of neonatal hyperbilirubinemia (odds ratio (OR) 0.25 , 95\% CI 0.68-0.88). ${ }^{61}$ Another RCT performed in 1000 pregnant women compared the incidence, maternal and fetal outcomes of GDM diagnosed using the one-step screening with IADPSG criteria versus two-step screening with GCT and diagnosis based on a $100 \mathrm{~g}$ OGTT with CC criteria. ${ }^{62}$ They found that the incidence of GDM using IADPSG criteria almost doubled (19.23\% vs $11.81 \%, \mathrm{p}=0.0001)$, and that maternal and neonatal outcomes were comparable in both groups except for lower rates of preterm delivery $(11.6 \%$ vs $24.1 \%$, relative risk (RR) 2.08 , 95\% CI $1.01-4.2, \mathrm{p}=0.046)$ and neonatal hypoglycemia $(7.4 \%$ vs $29.31 \%$, RR 3.98, 95\% CI 1.75-9.01, p $=0.003$ ) when using IADPSG criteria. Very recently, a large pragmatic RCT in about 23,000 pregnant women from the US evaluated the impact of a one-step screening strategy with IADPSG criteria compared with two-step screening with GCT and 100g OGTT using the CC criteria. They showed that despite a much higher rate of GDM diagnosis in the IADPSG group (16.5\% vs $8.5 \%$, ), there were no significant differences in perinatal and maternal complications between both groups. ${ }^{63}$ The Changing Diagnostic Criteria for Gestational diabetes (CDC4G) in Sweden study is an ongoing RCT (ISRCTN41918550) that also aims to evaluate whether treating women with GDM diagnosed by the IADPSG screening strategy will reduce the risks of adverse pregnancy outcomes. ${ }^{64}$ Another ongoing RCT (NCT02309138) involves 921 women to compare diagnosis of GDM and pregnancy outcomes according to the $\mathrm{CC}$ criteria compared with the IADPSG criteria. ${ }^{65}$

In conclusion, implementing the IADPSG screening strategy leads to a much higher prevalence of GDM without evidence of improvement pregnancy outcomes compared to a two-step screening strategy using the CC criteria for GDM. However, long-term follow-up studies are needed since women identified as GDM by the IADPSG screening strategy might be a higher risk population for diabetes and obesity postpartum. The HAPO Follow-up Study investigated whether GDM diagnosed with IADPSG criteria was associated with long-term risks for a disorder of glucose metabolism in mothers and greater adiposity in children. ${ }^{66}$ They found that GDM diagnosed with IADPSG criteria was significantly associated with maternal development of prediabetes or T2DM (OR 3.44 ), but not with childhood overweight or obesity at a median follow-up of 11.4 years. However, additional analysis showed that the children of these mothers had increased measures of adiposity and a higher risk of impaired glucose tolerance compared with offspring of mothers without GDM. ${ }^{67,68}$ With the increasing prevalence of GDM and potential transgenerational impact on the 
offspring, adequately powered interventional trials are needed to investigate the effect of prevention and treatment of GDM diagnosed with IADPSG criteria on long-term maternal and childhood outcomes.

\section{Screening Based on Risk Factors or Universal Screening for GDM}

The debate on the best way to screen for GDM continues, with conflicting recommendations for universal and selective screening. Over the past years, different screening tools have been proposed to diminish the need for an OGTT, but large inconsistencies exist regarding the specific screening procedures and outcomes that should necessitate diagnostic testing. The ongoing discussion is also due to the lack of RCTs that have evaluated whether universal screening for GDM leads to better pregnancy outcomes than selective screening for GDM.

In several guidelines, the decision for a diagnostic test is often still based on maternal risk factor assessment, ${ }^{69-72}$ but there is no clear consensus on which risk factors should be included in the decision-making process and whether this is an adequate approach to screen for GDM. Comparing the accuracy of different European selective screening guidelines to detect GDM, Benhalima et al showed that about $50 \%$ of pregnant women would need an OGTT with the lowest number of missed cases (33\%) by the Dutch guidelines. ${ }^{73}$ Various studies have confirmed that a risk-factor-based approach misses $5-45 \%$ of GDM cases $^{74-81}$ (Table 4). An argument for using a selective, risk-factor-based approach would be that women who are only detected as part of universal screening and not by risk-factor-based screening, have a milder form of GDM with similar pregnancy outcomes as the background pregnant population. A French retrospective cohort study found that selective screening based on risk factors would have missed one-sixth of GDM cases diagnosed with IADPSG criteria, but that these cases were milder, characterized by normal FPG, and that LGA was only associated with GDM in the presence of risk factors. ${ }^{80}$ A more recent retrospective study in more than 12,000 women confirmed that women with GDM diagnosed according to the IADPSG criteria without risk factors had fewer obstetric and neonatal complications compared with those having risk factors. ${ }^{82}$ In contrast, several studies showed that missed GDM cases without risk factors had worse pregnancy outcomes than women without GDM. ${ }^{77,78}$ For example, data from the Irish ATLANTICDIP study reported that selective screening based on risk factors in a Caucasian population missed $20 \%$ (using National Institute for Health and Care Excellence (NICE) criteria), 16\% (following Irish guidelines), and 5\% (with ADA guidelines) of women diagnosed with GDM using IADPSG criteria. ${ }^{78}$ Moreover, outcomes in these pregnancies were worse compared with normal glucose tolerance (NGT) pregnancies, including hypertensive disorders, cesarean sections, polyhydramnios, congenital malformations and NICU admissions. ${ }^{78}$ Often, the choice between universal and selective screening depends on the organization of prenatal care and the characteristics of the pregnant population, which differ widely internationally. In general, most guidelines such as the ADA, WHO and the International Federation of Gynecology and Obstetrics (FIGO) recommend universal screening in countries with enough resources, while alternative screening strategies can be used in low resource settings. ${ }^{1,2,83}$

\section{One-Step versus Two-Step Screening}

Several professional associations such as the American College of Obstetricians and Gynecologists (ACOG), the National Institute of Health (NIH), German and Flemish guidelines recommend a universal two-step screening strategy, using a non-fasting 50g GCT to limit the number of OGTTs that are needed. ${ }^{84-87}$ The GCT has the advantage that it can be performed in the non-fasting state, it is better tolerated and takes less time than the OGTT, and can therefore be easily implemented in primary care. The GCT has been used in combination with the 100g OGTT or the $75 \mathrm{~g}$ OGTT with various diagnostic criteria such as the CC criteria, the NDDG criteria, the 1999 WHO criteria, or the Canadian Diabetes Association criteria. A systematic review showed in 2013 that the sensitivity and specificity for the OGTT at a GCT threshold of $7.8 \mathrm{mmol} / \mathrm{L}$ after 1 hour were $70-88 \%$ and $69-89 \%$ respectively. At a threshold of $7.2 \mathrm{mmol} / \mathrm{L}$ after 1 hour, sensitivity varied between $88 \%$ and $99 \%$ and specificity between $66 \%$ and $77 \% .{ }^{88}$ More recently, the two-step screening strategy with diagnosis based on the 100g OGTT and CC criteria has been shown to lead to similar pregnancy outcomes compared to the one-step approach with IADPSG criteria, while it has the advantage that the number of OGTTs can be limited and that the prevalence of GDM is much lower ${ }^{63}$ (Table 3). A large Belgian multicentric prospective cohort study (BEDIP-N) has demonstrated that a GCT can also be used in a two-step screening strategy with the diagnosis of GDM based on a $75 \mathrm{~g}$ OGTT with the IADPSG $_{\text {criteria }^{89}}$ (Table 3). However, to have an 
Table 4 Selective Screening Based on Risk-Factors versus Universal Screening

\begin{tabular}{|c|c|c|c|c|c|c|}
\hline $\begin{array}{l}\text { Author, } \\
\text { Yearl } \\
\text { Country } \\
\text { (Ref.) }\end{array}$ & Design & $\begin{array}{l}\text { Subjects } \\
\text { (N) }\end{array}$ & $\begin{array}{l}\text { Study } \\
\text { Population }\end{array}$ & GDM Criteria & Comparison & Main Results \\
\hline $\begin{array}{l}\text { Cosson, 2006/ } \\
\text { France }^{77}\end{array}$ & $\begin{array}{l}\text { Observational } \\
\text { study }\end{array}$ & 4020 & $\begin{array}{l}\text { Singleton } \\
\text { pregnancies } \\
\text { without } \\
\text { ODIP }\end{array}$ & $\begin{array}{l}2 \mathrm{~h} 75 \mathrm{~g} \text { OGTT /FPG }>5.3 \\
\mathrm{mmol} / \mathrm{L} \text { (French } \\
\text { guidelines) or } 2 \mathrm{~h}>7.8 \\
\mathrm{mmol} / \mathrm{L} \text { (WHO 1999) or } \\
\text { both }\end{array}$ & $\begin{array}{l}\text { Selective (risk-factor } \\
\text { based) vs universal } \\
\text { screening }\end{array}$ & $\begin{array}{l}\text { Universal rather than } \\
\text { selective screening for } \\
\text { GDM may improve } \\
\text { outcomes as universal } \\
\text { screening might reduce } \\
\text { delay of diagnosis and } \\
\text { care }\end{array}$ \\
\hline $\begin{array}{l}\text { Dahanayaka, } \\
2012 / \text { Sri } \\
\text { Lanka }^{75}\end{array}$ & $\begin{array}{l}\text { Cross- } \\
\text { sectional } \\
\text { descriptive } \\
\text { study }\end{array}$ & 405 & $\begin{array}{l}\text { All pregnant } \\
\text { women }\end{array}$ & $\begin{array}{l}\text { IADPSG criteria vs } \\
\text { WHO } 1999 \text { criteria at } \\
24-28 \text { weeks }\end{array}$ & $\begin{array}{l}\text { GDM diagnosis based on } \\
\text { IADPSG criteria ( } 75 \mathrm{~g} \\
\text { OGTT) vs risk-factor } \\
\text { based approach (WHO } \\
\text { I999 criteria) }\end{array}$ & $\begin{array}{l}\text { The risk-factor based } \\
\text { approach missed } 38.9 \% \\
\text { of GDM cases }\end{array}$ \\
\hline $\begin{array}{l}\text { Arora, 2013/ } \\
\text { Thailand }^{74}\end{array}$ & $\begin{array}{l}\text { Cross- } \\
\text { sectional study }\end{array}$ & 593 & $\begin{array}{l}\text { All pregnant } \\
\text { women }\end{array}$ & $\begin{array}{l}\text { Ih } 50 \mathrm{~g} \text { GCT followed by, } \\
\text { if GCT } \geq 7.8 \mathrm{mmol} / \mathrm{L} \text {, } \\
\text { a } 3 \mathrm{~h} 100 \mathrm{~g} \text { OGTT/ACOG } \\
\text { (CC) criteria }\end{array}$ & $\begin{array}{l}\text { Risk vs non-risk factor } \\
\text { group }\end{array}$ & $\begin{array}{l}21.8 \% \text { of GDM cases had } \\
\text { no risk factor and only } \\
52.8 \% \text { of pregnant } \\
\text { women would enter the } \\
\text { screening process when } \\
\text { using risk-based } \\
\text { screening }\end{array}$ \\
\hline $\begin{array}{l}\text { Avalos, 2013/ } \\
\text { Ireland }^{78}\end{array}$ & $\begin{array}{l}\text { Retrospective } \\
\text { cohort study }\end{array}$ & 5500 & $\begin{array}{l}\text { All pregnant } \\
\text { women }\end{array}$ & $\begin{array}{l}2 \mathrm{~h} 75 \mathrm{~g} \text { OGTT at } 24-28 \\
\text { weeks/IADPSG criteria }\end{array}$ & $\begin{array}{l}\text { Universal (IADPSG) vs } \\
\text { selective GDM } \\
\text { screening (Irish vs ADA } \\
\text { vs NICE guidelines) }\end{array}$ & $\begin{array}{l}20 \% \text { (NICE), 16\% (Irish), } \\
\text { and 5\% (ADA) of women } \\
\text { with GDM had no risk } \\
\text { factor and would have } \\
\text { gone undiagnosed }\end{array}$ \\
\hline $\begin{array}{l}\text { Olagbuji, } \\
2015 / \text { Nigeria }^{81}\end{array}$ & $\begin{array}{l}\text { Prospective } \\
\text { observational } \\
\text { study }\end{array}$ & 1059 & $\begin{array}{l}\text { Singleton } \\
\text { pregnancies } \\
\text { without } \\
\text { T2DM }\end{array}$ & $\begin{array}{l}2 \mathrm{~h} 75 \mathrm{~g} \text { OGTT at } 24-32 \\
\text { weeks/IADPSG criteria }\end{array}$ & $\begin{array}{l}\text { Universal one-step ( } 75 \mathrm{~g} \\
\text { OGTT) vs risk factor } \\
\text { based GDM screening at } \\
24-32 \text { weeks using } \\
\text { WHO I999, WHO } \\
\text { 20I3/IADPSG criteria }\end{array}$ & $\begin{array}{l}20 \% \text { of GDM cases } \\
\text { would have been } \\
\text { undiagnosed if risk- } \\
\text { factor based approach } \\
\text { was employed }\end{array}$ \\
\hline $\begin{array}{l}\text { Miailhe, } 2015 / \\
\text { France }^{80}\end{array}$ & $\begin{array}{l}\text { Retrospective } \\
\text { cohort study }\end{array}$ & 2187 & $\begin{array}{l}\text { Singleton } \\
\text { pregnancies } \\
\text { without } \\
\text { ODIP }\end{array}$ & $\begin{array}{l}2 \mathrm{~h} 75 \mathrm{~g} \text { OGTT at } 24-28 \\
\text { weeks/IADPSG criteria }\end{array}$ & $\begin{array}{l}\text { Universal vs selective } \\
\text { (risk factors were those } \\
\text { recommended by the } \\
\text { IADPSG and French } \\
\text { guidelines) GDM } \\
\text { screening }\end{array}$ & $\begin{array}{l}\text { Selective screening } \\
\text { would have missed I7\% } \\
\text { of GDM cases diagnosed } \\
\text { with IADPSG criteria, } \\
\text { but these cases were } \\
\text { milder; LGA was } \\
\text { associated with GDM in } \\
\text { the presence but not in } \\
\text { de absence of risk } \\
\text { factors }\end{array}$ \\
\hline $\begin{array}{l}\text { Meththananda } \\
\text { Herath, 20I6/ } \\
\text { Sri Lanka }\end{array}$ & $\begin{array}{l}\text { Clinic-based } \\
\text { cross-sectional } \\
\text { study }\end{array}$ & 452 & $\begin{array}{l}\text { Pregnant } \\
\text { women } \\
\text { without } \\
\text { ODIP }\end{array}$ & $\begin{array}{l}2 \mathrm{~h} 75 \mathrm{~g} \text { OGTT at } 24-28 \\
\text { weeks/IADPSG criteria } \\
\text { and WHO } 1999 \text { criteria }\end{array}$ & $\begin{array}{l}\text { Risk factor based vs } \\
\text { universal screening using } \\
\text { IADPSG and WHO } \\
1999 \text { criteria }\end{array}$ & $\begin{array}{l}\text { Risk-based screening had } \\
\text { a lower detection rate of } \\
\text { GDM; however, it } \\
\text { reduced the necessity of } \\
\text { screening by } 20 \%\end{array}$ \\
\hline
\end{tabular}

(Continued) 
Table 4 (Continued).

\begin{tabular}{|c|c|c|c|c|c|c|}
\hline $\begin{array}{l}\text { Author, } \\
\text { Yearl } \\
\text { Country } \\
\text { (Ref.) }\end{array}$ & Design & $\begin{array}{l}\text { Subjects } \\
\text { (N) }\end{array}$ & $\begin{array}{l}\text { Study } \\
\text { Population }\end{array}$ & GDM Criteria & Comparison & Main Results \\
\hline $\begin{array}{l}\text { Agbozo, 2018/ } \\
\text { Ghana }^{76}\end{array}$ & $\begin{array}{l}\text { Prospective } \\
\text { blind } \\
\text { comparison } \\
\text { with a gold } \\
\text { standard study }\end{array}$ & 491 & $\begin{array}{l}\text { All pregnant } \\
\text { women } \geq 15 \\
\text { years } \\
\text { without } \\
\text { ODIP }\end{array}$ & $\begin{array}{l}\text { WHO } 2013 \text { criteria vs } \\
\text { NICE } 2015 \text { criteria }\end{array}$ & $\begin{array}{l}\text { Selective screening at } \\
\text { I3-20 weeks using } \\
\text { reagent-strip glycosuria } \\
\text { vs RPG vs presence of } \\
\geq 1 \text { risk factor(s) vs } \\
\text { universal screening at } \\
20-34 \text { weeks following } \\
\text { the 'one-step' approach }\end{array}$ & $\begin{array}{l}\text { Use of risk factors is } \\
\text { a better screening tool } \\
\text { compared to glycosuria/ } \\
\text { RPG because risk factors } \\
\text { would miss } \pm 50 \% \text { of the } \\
\text { true positive rate, } \\
\text { whereas glycosuria and } \\
\text { RPG would miss } \pm 90 \%\end{array}$ \\
\hline $\begin{array}{l}\text { Benhalima, } \\
2019 / \\
\text { Belgium }^{73}\end{array}$ & $\begin{array}{l}\text { Retrospective } \\
\text { analysis of } \\
\text { prospectively } \\
\text { collected data }\end{array}$ & 1811 & $\begin{array}{l}\text { Singleton } \\
\text { pregnancies } \\
\text { without } \\
\text { ODIP and } \\
\text { history of } \\
\text { bariatric } \\
\text { surgery }\end{array}$ & $\begin{array}{l}2013 \text { WHO criteria vs } \\
\text { NICE } 2015 \text { (English) } \\
\text { guidelines vs Irish } \\
\text { guidelines from } 2010 \text { vs } \\
\text { French guidelines from } \\
2010 \text { vs Dutch guidelines } \\
\text { from } 2010\end{array}$ & $\begin{array}{l}\text { Universal screening ( } 75 \mathrm{~g} \\
\text { OGTT) vs selective } \\
\text { screening according to } \\
\text { NICE } 2015 \text { vs Irish } \\
\text { guidelines from } 2010 \text { vs } \\
\text { French guidelines from } \\
2010 \text { vs Dutch guidelines } \\
\text { from } 2010\end{array}$ & $\begin{array}{l}\text { By applying selective } \\
\text { screening by most } \\
\text { European guidelines, } \\
\text { about } 50 \% \text { of women } \\
\text { would need an OGTT } \\
\text { with the lowest number } \\
\text { of missed cases (33\%) by } \\
\text { Dutch guidelines; GDM } \\
\text { women without risk } \\
\text { factors had higher rates } \\
\text { of neonatal hypoglycemia } \\
\text { than NGT women }\end{array}$ \\
\hline $\begin{array}{l}\text { Matta- } \\
\text { Coelho, 2019/ } \\
\text { Portugal }^{82}\end{array}$ & $\begin{array}{l}\text { Retrospective } \\
\text { cohort study }\end{array}$ & 10,443 & $\begin{array}{l}\text { All pregnant } \\
\text { women }\end{array}$ & $\begin{array}{l}2 \mathrm{~h} 75 \mathrm{~g} \text { OGTT at } 24-28 \\
\text { weeks/IADPSG criteria }\end{array}$ & $\begin{array}{l}\text { Universal vs risk factor } \\
\text { based GDM screening }\end{array}$ & $\begin{array}{l}31.8 \% \text { would have } \\
\text { remained undiagnosed if } \\
\text { risk factor based } \\
\text { screening was } \\
\text { implemented and } \\
\text { women with risk factors } \\
\text { diagnosed with GDM on } \\
\text { universal screening } \\
\text { presented worse } \\
\text { obstetric and neonatal } \\
\text { outcomes }\end{array}$ \\
\hline
\end{tabular}

Abbreviations: GDM, gestational diabetes mellitus; IADPSG, International Association of the Diabetes and Pregnancy Study Groups; OGTT, oral glucose tolerance test; WHO, World Health Organization; ADA, American Diabetes Association; NICE, National Institute for Health and Care Excellence; T2DM, type 2 diabetes mellitus; FPG, fasting plasma glucose; LGA, large-for-gestational age; RPG, random plasma glucose; HbAIc, hemoglobin AIC; ODIP, overt diabetes in pregnancy; NGT, normal glucose tolerance.

acceptable sensitivity to screen for GDM with the IADPSG criteria, the threshold of the GCT should be lowered from 7.8 to $7.2 \mathrm{mmol} / \mathrm{L}$ after 1 hour. In our center, a modified two-step screening strategy combining the $\mathrm{GCT} \geq 7.2 \mathrm{mmol} / \mathrm{L}$ with clinical risk factors is applied. ${ }^{87}$ Women with a BMI $\geq 30 \mathrm{~kg} / \mathrm{m}^{2}$ and/or a previous history of GDM immediately receive a 75g OGTT with the use of IAPDSG criteria at 24 weeks since they are at high risk for GDM, while women without any of these risk factors would be screened with a $50 \mathrm{~g}$ GCT. This strategy can reduce the workload and the need for an OGTT in nearly $60 \%$ of the women while reducing the number of women that would be missed with GDM.

\section{Additional Screening Methods}

An overview of studies investigating additional screening methods for GDM to limit the number of OGTTs needed is given in Table 5 .

An FPG at the time of screening for GDM between 24 and 26 weeks of pregnancy can be used to decide whether 
Table 5 Use of FPG, HbAlc or PGCD59 as a Screening Tool

\begin{tabular}{|c|c|c|c|c|c|}
\hline $\begin{array}{l}\text { Author, } \\
\text { Yearl } \\
\text { Country } \\
\text { (Ref.) }\end{array}$ & Design & $\begin{array}{l}\text { Subjects } \\
\text { (N) }\end{array}$ & $\begin{array}{l}\text { Study } \\
\text { Population }\end{array}$ & Comparison & Main Results \\
\hline \multicolumn{6}{|l|}{ FPG } \\
\hline $\begin{array}{l}\text { Agarwal, } \\
2010 / \mathrm{UAE}^{45}\end{array}$ & $\begin{array}{l}\text { Retrospective } \\
\text { cohort study }\end{array}$ & 10,283 & $\begin{array}{l}\text { All pregnant } \\
\text { women } \\
\text { screened for } \\
\text { GDM at 24-28 } \\
\text { weeks }\end{array}$ & $\begin{array}{l}\text { GDM diagnosis based on IADPSG vs } \\
\text { ADA criteria } / F P G ~ \geq 4.2 \mathrm{mmol} / \mathrm{L} \text { vs } \\
\geq 4.4 \mathrm{mmol} / \mathrm{L} \text { vs } \geq 4.7 \mathrm{mmol} / \mathrm{L} \text { vs } 5.0 \\
\mathrm{mmol} / \mathrm{L} \text { vs } 5.1 \mathrm{mmol} / \mathrm{L}\end{array}$ & $\begin{array}{l}\text { Rule-in/rule-out approach for FPG to } \\
\text { predict GDM with FPG } \geq 5.1 \mathrm{mmol} / \mathrm{L} \\
\text { ruling in GDM in } 28.9 \% \text { of women } \\
\text { with } 100 \% \text { specificity and } \mathrm{FPG}<4.4 \\
\mathrm{mmol} / \mathrm{L} \text { ruling out GDM in } 21.7 \% \\
\text { women at a sensitivity of } 95.4 \% \text {, } \\
\text { eliminating half of the OGTTs } \\
\text { needed }\end{array}$ \\
\hline $\begin{array}{l}\text { Göbl, 20I2/ } \\
\text { Austria }^{93}\end{array}$ & $\begin{array}{l}\text { Secondary } \\
\text { analysis of } \\
\text { a prospective } \\
\text { cohort study }\end{array}$ & 1336 & $\begin{array}{l}\text { Women without } \\
\text { ODIP }\end{array}$ & $\begin{array}{l}\text { Elaboration of a screening algorithm } \\
\text { combining (I) FPG and ( } 2 \text { ) } \\
\text { a multivariable risk estimation model } \\
\text { focused on individuals with normal } \\
\text { FPG levels to decide if a further } \\
\text { OGTT is indicated }\end{array}$ & $\begin{array}{l}\text { A risk estimation model in addition } \\
\text { to FPG was accurate for detecting } \\
\text { GDM in participants with normal } \\
\text { FPG }\end{array}$ \\
\hline $\begin{array}{l}\text { Maesa, 2018/ } \\
\text { Spain }^{92}\end{array}$ & $\begin{array}{l}\text { Retrospective } \\
\text { study }\end{array}$ & 6573 & $\begin{array}{l}\text { All pregnant } \\
\text { women }\end{array}$ & $\begin{array}{l}\text { Three groups: normal glycaemia vs } \\
\text { glucose intolerance (I point in } \\
\text { OGTT equal or above established } \\
\text { thresholds) vs GDM diagnosis }\end{array}$ & $\begin{array}{l}\text { Women with FPG } \leq 3.4 \mathrm{mmol} / \mathrm{L} \text { were } \\
\text { at low risk of developing GDM with } \\
\text { a sensitivity of } 91.3 \% \text {, thereby } \\
\text { avoiding a two-step screening in } 10 \% \\
\text { of their population }\end{array}$ \\
\hline $\begin{array}{l}\text { Saeedi, 2018/ } \\
\text { Sweden }^{91}\end{array}$ & $\begin{array}{l}\text { Cross- } \\
\text { sectional } \\
\text { population- } \\
\text { based study }\end{array}$ & 3616 & $\begin{array}{l}\text { All pregnant } \\
\text { women }\end{array}$ & $\begin{array}{l}\text { Risk factors and FPG vs IADPSG } \\
\text { criteria for GDM diagnosis }\end{array}$ & $\begin{array}{l}\text { Risk factor screening for GDM was } \\
\text { poorly predictive, but FPG of } 4.8-5.0 \\
\mathrm{mmol} / \mathrm{L} \text { high sensitivity and specificity } \\
\text { irrespective of diagnostic model and } \\
\text { resulted in a low rate of OGTTs }\end{array}$ \\
\hline $\begin{array}{l}\text { Dickson, } \\
\text { 2020/South } \\
\text { Africa }^{90}\end{array}$ & $\begin{array}{l}\text { Cross- } \\
\text { sectional } \\
\text { prospective } \\
\text { study }\end{array}$ & 589 & $\begin{array}{l}\text { Pregnant } \\
\text { women without } \\
\text { ODIP }<28 \\
\text { weeks }\end{array}$ & $\begin{array}{l}\text { Selective screening (risk factor } \\
\text { based) vs universal application of FPG } \\
\geq 4.5 \mathrm{mmol} / \mathrm{L} \text { to identify women with } \\
\text { GDM }\end{array}$ & $\begin{array}{l}\text { Universal screening using FPG } \geq 4.5 \\
\text { mmol/L had greater sensitivity and } \\
\text { specificity in identifying GDM and } \\
\text { required fewer women to undergo } \\
\text { a resource-intensive diagnostic } \\
\text { OGTT than selective screening }\end{array}$ \\
\hline \multicolumn{6}{|l|}{ FPG } \\
\hline $\begin{array}{l}\text { O'Connor, } \\
\text { 20I2/Ireland }\end{array}$ & $\begin{array}{l}\text { Prospective } \\
\text { cohort study }\end{array}$ & 311 & $\begin{array}{l}\text { Non-diabetic } \\
\text { Caucasian } \\
\text { pregnant and } \\
\text { non-pregnant } \\
\text { women }\end{array}$ & $\begin{array}{l}\text { Non-pregnant vs TI (trimester I) vs } \\
\text { T2 vs T3 }\end{array}$ & $\begin{array}{l}\mathrm{HbAlc} \text { trimester-specific reference } \\
\text { intervals are required to better } \\
\text { inform the management of } \\
\text { pregnancies complicated by diabetes }\end{array}$ \\
\hline $\begin{array}{l}\text { Lowe, 2012/ } \\
\text { International }^{96}\end{array}$ & $\begin{array}{l}\text { Secondary } \\
\text { analysis of } \\
\text { a prospective } \\
\text { cohort study }\end{array}$ & 21,064 & $\begin{array}{l}\text { Singleton } \\
\text { pregnancies } \\
\text { without ODIP }\end{array}$ & $\begin{array}{l}\text { Association of } \mathrm{HbAl} \text { lc and model I vs } \\
\text { model } 2 \text { vs model } 3\end{array}$ & $\begin{array}{l}\text { Associations were significantly } \\
\text { stronger with glucose measures than } \\
\text { with HbAIC for adverse neonatal } \\
\text { outcomes, suggesting that } \\
\text { measurement of HbAIc is not } \\
\text { a useful alternative to an OGTT for } \\
\text { diagnosing GDM in pregnant women }\end{array}$ \\
\hline
\end{tabular}


Table 5 (Continued).

\begin{tabular}{|c|c|c|c|c|c|}
\hline $\begin{array}{l}\text { Author, } \\
\text { Yearl } \\
\text { Country } \\
\text { (Ref.) }\end{array}$ & Design & $\begin{array}{l}\text { Subjects } \\
\text { (N) }\end{array}$ & $\begin{array}{l}\text { Study } \\
\text { Population }\end{array}$ & Comparison & Main Results \\
\hline $\begin{array}{l}\text { Rajput, 2012/ } \\
\text { India }^{49}\end{array}$ & $\begin{array}{l}\text { Prospective } \\
\text { cohort study }\end{array}$ & 607 & $\begin{array}{l}\text { Women without } \\
\text { ODIP }\end{array}$ & $\begin{array}{l}\text { ADA vs IADPSG criteria/OGTT in } \\
\text { combination with } \mathrm{HbAlc}<5.45 \% \text { vs } \\
5.45-5.95 \% \text { vs }>5.95 \%\end{array}$ & $\begin{array}{l}\text { HbAlc in combination with an } \\
\text { OGTT obviated the need of OGTT } \\
\text { in } 61.8 \% \text { of GDM cases and HbAlc } \\
>5.95 \% \text { could be used to diagnose } \\
\text { GDM in pregnant women with } \\
\text { a specificity of } 92.7 \%\end{array}$ \\
\hline $\begin{array}{l}\text { Renz, 2015/ } \\
\text { Brazil }^{97}\end{array}$ & $\begin{array}{l}\text { Diagnostic } \\
\text { test accuracy } \\
\text { study }\end{array}$ & 262 & $\begin{array}{l}\text { Pregnant } \\
\text { women without } \\
\text { ODIP }\end{array}$ & $\begin{array}{l}\text { Reference test (OGTT) vs index test } \\
\text { (HbAlc)/sensitivity, specificity and } \\
\text { likelihood ratios of different HbAlc } \\
\text { cut-off points }\end{array}$ & $\begin{array}{l}\text { Different HbAlc cut-off points in } \\
\text { combination with an OGTT may be } \\
\text { a useful diagnostic tool for GDM }\end{array}$ \\
\hline $\begin{array}{l}\text { Khalafallah, } \\
2016 / \\
\text { Australia }^{99}\end{array}$ & $\begin{array}{l}\text { Prospective } \\
\text { cohort study }\end{array}$ & 480 & $\begin{array}{l}\text { Singleton } \\
\text { pregnancies } \\
\text { without early } \\
\text { GDM diagnosis } \\
\text { (<24 weeks) }\end{array}$ & $\begin{array}{l}\text { HbAlc levels (4.6-10\%) vs OGTT } \\
\text { results }\end{array}$ & $\begin{array}{l}\text { Pregnant women with an } \mathrm{HbAlc} \text { of } \\
\geq 5.4 \% \text { should proceed with an } \\
\text { OGTT, resulting in a significant } \\
\text { reduction in the burden of testing }\end{array}$ \\
\hline $\begin{array}{l}\text { Odsaeter, } \\
2016 / \\
\text { Norway }^{100}\end{array}$ & $\begin{array}{l}\text { Retrospective } \\
\text { analysis of } \\
\text { RCT data }\end{array}$ & 677 & $\begin{array}{l}\text { Singleton viable } \\
\text { pregnancies } \\
\text { without high } \\
\text { risk }\end{array}$ & $\begin{array}{l}\text { HbAlc levels alone or in } \\
\text { combination with patient } \\
\text { characteristics and GDM-WHO vs } \\
\text { GDM-IADPSG }\end{array}$ & $\begin{array}{l}\text { HbAlc may have a potential for } \\
\text { screening for GDM since it is } \\
\text { possible to exclude GDM in } \\
\text { a significant proportion of women } \\
\text { and could therefore reduce the } \\
\text { number of OGTTs }\end{array}$ \\
\hline \multicolumn{6}{|l|}{ pGCD59 } \\
\hline $\begin{array}{l}\text { Ghosh, 2017/ } \\
\text { US }^{102}\end{array}$ & $\begin{array}{l}\text { Case-control } \\
\text { study }\end{array}$ & 1000 & $\begin{array}{l}\text { Women } \\
\text { undergoing } \\
\text { routine two- } \\
\text { step GDM } \\
\text { screening }\end{array}$ & $\begin{array}{l}\text { PGCD59 in women with normal } \\
\text { GCT (control subjects) vs women } \\
\text { with a failed GCT and a subsequent } \\
\text { OGTT (case patients) }\end{array}$ & $\begin{array}{l}\text { One pGCD59 measurement during } \\
\text { weeks } 24-28 \text { identified pregnancy- } \\
\text { induced glucose intolerance with high } \\
\text { sensitivity and specificity and could } \\
\text { potentially identify the risk for LGA }\end{array}$ \\
\hline $\begin{array}{l}\text { Ma, 2020/ } \\
\text { Europe }\end{array}$ & $\begin{array}{l}\text { Ancillary } \\
\text { descriptive } \\
\text { study }\end{array}$ & 693 & $\begin{array}{l}\text { Obese women } \\
(\mathrm{BMl}>29) \\
\text { undergoing } \\
\text { a } 75 \mathrm{~g}, 2 \mathrm{~h} \text { OGTT } \\
\text { at }<20 \text { weeks }\end{array}$ & $\begin{array}{l}\text { pGCD59 in NGT women vs GDM } \\
\text { diagnosed }<20 \text { weeks vs GDM } \\
\text { diagnosed } 24-28 \text { weeks }\end{array}$ & $\begin{array}{l}\text { PGCD59 accurately identified GDM } \\
\text { in early pregnancy; One-unit increase } \\
\text { in maternal PGCD59 level was } \\
\text { associated with } 36 \% \text { increased odds } \\
\text { of delivering an LGA infant }\end{array}$ \\
\hline $\begin{array}{l}\text { Bogdanet, } \\
2020 \\
\text { (ongoing)/ } \\
\text { Ireland }^{104}\end{array}$ & $\begin{array}{l}\text { Prospective } \\
\text { cohort study }\end{array}$ & \pm 2000 & $\begin{array}{l}\text { Pregnant } \\
\text { women without } \\
\text { ODIP }\end{array}$ & $\begin{array}{l}\text { PGCD59 at first antenatal visit, } 24- \\
28 \text { weeks, in T3 and at } 12 \text { weeks } \\
\text { postpartum vs } 75 \text { g OGTT/ sensitivity } \\
\text { and specificity of PGCD59 to predict } \\
\text { the results of the OGTT, adverse } \\
\text { outcomes and/or postpartum } \\
\text { glucose intolerance }\end{array}$ & No results published yet \\
\hline
\end{tabular}

Abbreviations: UAE, United Arab Emirates; GDM, gestational diabetes mellitus; IADPSG, International Association of the Diabetes and Pregnancy Study Groups; ODIP, overt diabetes in pregnancy; ADA, American Diabetes Association; FPG, fasting plasma glucose; OGTT, oral glucose tolerance test; GCT, glucose challenge test; NDDG, National Diabetes Data Group; WHO, World Health Organization; HbAlc, hemoglobin AIC; PGCD59, plasma glycatedCD59; LGA, large for gestational age; BMI, body mass index. 
a full OGTT is needed for the diagnosis of GDM. When FPG is $\geq 5.1 \mathrm{mmol} / \mathrm{L}$, GDM can be diagnosed according to the IADPSG criteria and an OGTT can be avoided. ${ }^{2}$ Alternatively, an FPG threshold with a high negative predictive value for GDM could be applied (in low resource settings) to reduce the number of women requiring an OGTT and at the same time avoiding missed diagnoses. In 2010, a retrospective cohort study in a South Asian population suggested a rule-in/rule-out approach for the FPG to predict GDM, with a higher FPG threshold of $\geq 5.1$ $\mathrm{mmol} / \mathrm{L}$ ruling in GDM in $28.9 \%$ of women with $100 \%$ specificity and a lower FPG threshold of $<4.4 \mathrm{mmol} / \mathrm{L}$ ruling out GDM in $21.7 \%$ women at an acceptable sensitivity of $95.4 \%{ }^{45}$ This approach could eliminate half of the OGTTs needed to diagnose GDM, thereby providing relief to health-delivery systems in countries with highrisk populations. More recently, a prospective study in South-African women confirmed that universal screening using FPG $\geq 4.5 \mathrm{mmol} / \mathrm{L}$ had greater sensitivity and specificity in identifying GDM-affected women and required fewer women to undergo a resource-intensive diagnostic OGTT than risk-factor-based selective screening. ${ }^{90}$ Likewise, a retrospective study found that risk factor screening for GDM alone or in combination with random capillary glucose was poorly predictive of GDM, but FPG 4.8-5.0 mmol/1 showed good test characteristics and resulted in a low rate of OGTTs needed. ${ }^{91}$ A study evaluating FPG as a screening tool to rule-out GDM in a lowrisk population found that women with $\mathrm{FPG} \leq 3.4 \mathrm{mmol} / \mathrm{L}$ were at low risk of developing GDM with a sensitivity of $91.3 \%$, thereby avoiding a two-step screening in $10 \%$ of their population. ${ }^{92}$

Some authors suggest that sensitivity and specificity for risk-factor based GDM screening could be considerably improved by using clinical risk prediction models that include combinations of several risk indicators in combination with FPG for improved prediction. For example, an estimation model developed by an Austrian research group (including history of GDM, glycosuria, family history of diabetes, age, preconception dyslipidemia and ethnic origin, in addition to FPG) showed that it was accurate for detecting GDM in participants with normal FPG. The ROC AUC of the screening algorithm was $0.90(95 \%$ CI $0.88,0.91)$ and a cut-off value of 0.20 was able to differentiate between low and intermediate risk for GDM with a high sensitivity. ${ }^{93}$ More recent research is also focused on the use of risk models to connect hyperglycemia in pregnancy (HIP) with adverse pregnancy outcomes. A risk calculator developed by an Australian research group integrated the risks of hyperglycemia, maternal BMI and other basic demographic data available at the OGTT, and had a superior performance on ROC analysis for predicting an individual's absolute risk of adverse pregnancy outcomes compared to the existing GDM diagnostic criteria. $^{94}$ The Prediction for Risk-Stratified care for women with GDM (PeRSonal GDM) study is still ongoing and will develop, validate and evaluate the clinical utility of a prediction model for adverse pregnancy outcomes in women with GDM. ${ }^{95}$ These models show promise for use in clinical practice, but further research and development is necessary.

Several studies evaluated the usefulness of an $\mathrm{HbAlc}$ measurement for the diagnosis of GDM. In the large HAPO study cohort, associations were significantly stronger with glucose measures than with $\mathrm{HbA} 1 \mathrm{C}$ for different adverse neonatal outcomes, suggesting that measurement of $\mathrm{HbAlc}$ is not a useful alternative to an OGTT for diagnosing GDM in pregnant women. ${ }^{96}$ Later studies confirmed that even though HbAlc measurement does not have sufficient sensitivity and specificity to be used as the only diagnostic test for GDM, different HbA1c thresholds in combination with an OGTT could be useful in detecting $\mathrm{GDM}^{49,97-100}$. In 2019, a systematic review bundled the results of eight studies that investigated the accuracy of $\mathrm{HbAlc}$ in the diagnosis of GDM. ${ }^{101}$ The diagnostic accuracy of HbA1c was reported at different thresholds ranging from $5.4 \%$ to $6.0 \%$, and the AUC was 0.825 (95\% CI 0.751-0.899), indicating a good level of overall accuracy. They concluded that the HbA1c test presented high specificity but low sensitivity regardless of the threshold used to diagnose GDM. Therefore, HbA1c could be useful as a rulein test in association with standard diagnostic tools such as an OGTT to diagnose GDM.

Globally, researchers are working to identify biomarkers that may have potential future application in diagnosing women with GDM. One such promising biomarker is plasma glycated CD59 (pGCD59), a cell membraneanchored complement regulatory protein that protects "self" cells from complement-mediated damage. A casecontrol study evaluated levels of pGCD59 in plasma samples from 1000 women who underwent routine screening and diagnosis of GDM. It was the first study to demonstrate that a single measurement of pGCD59 at 24-28 weeks of gestation could identify women with GDM 
with high sensitivity and specificity, and that it could potentially identify the risk for LGA. ${ }^{102}$ More recently, these findings were confirmed by Ma et al, showing that pGCD59 in pregnant women before 20 weeks of pregnancy accurately predicts the results of the OGTT and that pGCD59 levels were associated with a higher risk of delivering an LGA infant. ${ }^{103}$ However, prospective studies are needed to confirm the clinical utility of pGCD59 as a biomarker for detection and diagnosis of GDM. An ongoing study aims to prospectively examine the validity of pGCD59 as a biomarker for the prediction, diagnosis, management and follow-up of women with GDM diagnosed using IADPSG criteria in a one-step approach in an unselected pregnant population. ${ }^{104}$

Two recent systematic reviews elucidated the potential role of other first-trimester biochemical predictors such as inflammatory markers (C-reactive protein, tumor necrosis factor-alpha), insulin resistance markers (fasting insulin, sex hormone-binding globulin), adipocyte-derived markers (adiponectin, leptin) and placenta-derived markers (follistatin-like-3, placental growth factor, placental exosomes). ${ }^{105,106}$ However, to convert the findings from observational studies of these biomarkers to clinical practice, strategies that use first-trimester biomarkers to avoid additional screening for GDM should be examined for effects on outcomes and costs.

\section{Screening After Bariatric Surgery}

Bariatric surgery (BS) is an effective way to reduce the risk for GDM in obese women. ${ }^{107}$ Nevertheless, women often remain overweight after BS and the risk to develop GDM is generally still higher compared to pregnant women with a normal weight. Therefore, screening for GDM is still required in women with a history of BS. However, the diagnosis of GDM after BS is challenging, since an OGTT can trigger dumping syndromes with serious adverse effects. In addition, wide variations in glucose excursions and reactive hypoglycemia on the OGTT have been reported in pregnant women with a history of BS. ${ }^{108-110}$ An OGTT is therefore not recommended to use in pregnant women with BS. Guidelines on screening for GDM in women with BS are lacking and there is no evidence that treatment of GDM diagnosed with an OGTT leads to improved pregnancy outcomes in this population. ${ }^{109}$ A recent narrative review ${ }^{111}$ summarized the results of studies that tested different screening strategies for GDM after BS, and concluded that capillary blood glucose measurements may currently be the most acceptable alternative to the OGTT for screening in pregnancy after BS. They suggested a pragmatic approach in which all pregnant women with a history of BS are screened at 24-28 weeks of pregnancy by recording capillary blood glucose daily before and after meals during 3-7 days. For the diagnostic and intervention glycemic targets, the same treatment targets as recommended by the ADA were proposed $(\mathrm{FPG}<5.3 \mathrm{mmol} / \mathrm{L}, 1 \mathrm{~h}$ after the meal $<7.8$ $\mathrm{mmol} / \mathrm{L}$ or $2 \mathrm{~h}$ after the meal $<6.7 \mathrm{mmol} / \mathrm{L}$ ). More research is needed to define optimal glycemic targets in this population. In addition, as an alternative to capillary blood glucose measurements, continuous glucose measurement (CGM) should be evaluated for the diagnosis of GDM. Large studies are needed to evaluate the association between glycemic metrics from the CGM with pregnancy outcomes in this population.

\section{Screening in Times of COVID-19}

Due to the COVID-19 pandemic, screening for GDM might lead to an increased risk for exposure to the virus. Temporary changes to diagnostic testing procedures for GDM have been recommended. Several large observational studies described how screening for GDM could be organized in a pragmatic way using blood tests and risk calculators (Table 6).

McIntyre et al described how altered diagnostic processes and criteria for GDM during COVID-19 in Australia, Canada and the United Kingdom (UK) would affect GDM frequency and adverse outcomes. ${ }^{112,113}$ They showed that the COVID-19 diagnostic approaches reduced GDM frequency by $81 \%$ in the UK, by $82 \%$ in Canada and by $25 \%$ in Australia. Missed GDM cases in Canada displayed similar rates of pregnancy complications to those with GDM, while using UK and Australian modifications, the missed GDM group was respectively at slightly and substantially lower risk. Meek et al ${ }^{114}$ reported that women with hyperglycemia at risk of suboptimal pregnancy outcomes were identified with an $\mathrm{RPG} \geq 8.5 \mathrm{mmol} / \mathrm{L}$ at 12 weeks, and an FPG $\geq 5.2-5.4 \mathrm{mmol} / \mathrm{L}$ or $\mathrm{HbAlc} \geq 5.7 \%$ at 28 weeks of pregnancy. They recommended using these easy-to-perform laboratory tests when an OGTT is not possible. Thangaratinam et al suggested to undertake additional tests at booking to detect overt diabetes and identify those at highest risk for GDM. ${ }^{115}$ At 24 weeks, they recommended to combine FPG with HbAlc to improve the detection rate, since evidence showed that using FPG alone will only pick up about half of all women with GDM, based on NICE or IADPSG criteria. Furthermore, 
Table 6 Screening During the COVID-19 Pandemic

\begin{tabular}{|c|c|c|}
\hline Author, Year/Country (Ref.) & Pragmatic Approach & Main Results \\
\hline Torlone, $2020 /$ Italy $^{117}$ & $\begin{array}{l}\text { Screening for overt diabetes: } F P G \geq 6.9 \mathrm{mmol} / \mathrm{L} \text { or } \\
\text { RPG } \geq I \mathrm{I} . \mathrm{Immol} / \mathrm{L} \text { or } \mathrm{HbAlc} \geq 6.5 \% \\
\text { A single value can be considered valid during } \\
\text { COVID- } 19 \text { emergency } \\
\text { Screening for GDM: risk factors assessment } \\
\text { Women at high risk for GDM: FPG } \geq 5.1 \mathrm{mmol} / \mathrm{L} \text { at } \\
16-18 \text { weeks } \rightarrow \text { GDM } \\
\text { Women at high risk for GDM: FPG } \leq 5.1 \mathrm{mmol} / \mathrm{L} \text { at } \\
16-18 \text { weeks } \rightarrow \text { FPG at } 24-28 \text { weeks } \geq 5.1 \mathrm{mmol} / \mathrm{L} \\
\rightarrow \text { GDM } \\
\text { Women at medium risk for GDM: FPG } \geq 5.1 \mathrm{mmol} / \mathrm{L} \\
\text { at } 24-28 \text { weeks } \rightarrow \text { GDM }\end{array}$ & $\begin{array}{l}\text { An FPG value can be considered diagnostic for } \\
\text { GDM only when it is obtained at the gestational age } \\
\text { when the OGTT should have been carried out (I6- } \\
18 \text { weeks in high-risk pregnant women or 24-28 } \\
\text { weeks in medium-risk women) }\end{array}$ \\
\hline $\begin{array}{l}\text { Mclntyre, } 2020 \text { (Diagnosis and } \\
\text { management of GDM during } \\
\text { COVID-19)/UK, Canada and } \\
\text { Australia' } 12\end{array}$ & 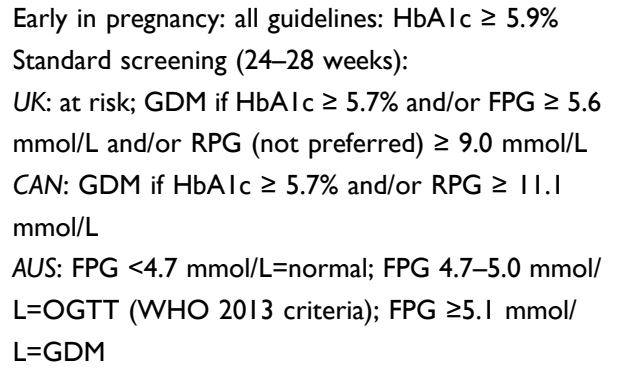 & Detecting only those with marked hyperglycemia \\
\hline Thangaratinam, $2020^{115}$ & $\begin{array}{l}\text { Early GDM screening: additional tests at booking } \\
\text { (HbAlc and RPG) to detect overt diabetes and } \\
\text { identify those at highest risk for GDM. Suggested } \\
\text { thresholds and actions: } \\
\text { HbAIc } \geq 6.5 \% \text { or RPG } \geq 11 . I \text { mmol/L: treat as } \\
\text { preexisting diabetes. } \\
\text { HbAIc } 5.9-6.5 \% \text { or RPG 9-II mmol/L: consider } \\
\text { managing using the GDM pathway. } \\
\text { Avoid OGTT at } 24-28 \text { weeks and instead offer } \\
\text { HbAIc along with FPG or RPG if fasting values are } \\
\text { not available } \\
\text { Suggested thresholds and actions: HbAlc } \geq 5.7 \% \text { or } \\
\text { FPG } \geq 5.6 \mathrm{mmol} / \mathrm{L} \text { or RPG } \geq 9 \mathrm{mmol} / \mathrm{L}: \text { treat as GDM. }\end{array}$ & $\begin{array}{l}\text { Using FPG alone will only pick up half of all women } \\
\text { with GDM, based on NICE or IADPSG criteria. } \\
\text { Combining FPG with HbAIc may improve the } \\
\text { detection rate. Maintaining existing FPG thresholds } \\
\text { may be preferable, and services may consider lower } \\
\text { thresholds consistent with the IADPSG diagnostic } \\
\text { criteria (FPG } \geq 5.1 \text { ) if resources allow }\end{array}$ \\
\hline Van Gemert, 2020/Australia ${ }^{1 / 9}$ & $\begin{array}{l}\text { ADIPS temporary criteria during the COVID-19 } \\
\text { pandemic are based on the Queensland Clinical } \\
\text { Guidelines: } \\
\text { HbAIc measurement in the first trimester for women } \\
\text { with risk factors } \\
\text { FPG at } 24-28 \text { weeks gestation for women not already } \\
\text { diagnosed with GDM } \rightarrow \text { GDM diagnosis if FPG is } \geq 5 \text {.I } \\
\mathrm{mmol} / \mathrm{L} \text {, no OGTT required if FPG } \leq 4.6 \mathrm{mmol} / \mathrm{L} \text {, } \\
\text { OGTT recommended if FPG of } 4.7-5.0 \mathrm{mmol} / \mathrm{L}\end{array}$ & $\begin{array}{l}\text { Using a FPG } \leq 4.6 \mathrm{mmol} / \mathrm{L} \text { as cut-off to determine } \\
\text { that a } 75 \mathrm{~g} 2 \mathrm{~h} \text { OGTT is not necessary will reduce the } \\
\text { number of women being potentially exposed, but } \\
\text { would miss nearly a third of GDM cases }\end{array}$ \\
\hline $\begin{array}{l}\text { Meek, 2020/UK, Canada, New } \\
\text { Zealand and Australia'1/4 }\end{array}$ & $\begin{array}{l}\text { To evaluate the diagnostic and prognostic } \\
\text { performance of alternative diagnostic strategies to } \\
2 \mathrm{~h} 75 \mathrm{~g} \text { OGTTs: HbAIc, RPG and FPG } \\
\text { GDM diagnosis: criteria of the UK National Institute } \\
\text { for Health and Care Excellence and IADPSG criteria }\end{array}$ & $\begin{array}{l}\text { RPG at } 12 \text { weeks, and FPG or HbAlc at } 28 \text { weeks } \\
\text { identify women with hyperglycemia at risk of } \\
\text { suboptimal pregnancy outcomes }\end{array}$ \\
\hline
\end{tabular}

(Continued) 
Table 6 (Continued).

\begin{tabular}{|c|c|c|}
\hline Author, Year/Country (Ref.) & Pragmatic Approach & Main Results \\
\hline $\begin{array}{l}\text { Mclntyre, } 2020 \text { (Testing for GDM } \\
\text { during COVID-19)/UK, Canada and } \\
\text { Australia }^{1 / 3}\end{array}$ & $\begin{array}{l}\text { UK: Risk factor based; no OGTT; GDM if } \mathrm{HbAlc} \geq \\
5.7 \% \text { and/or FPG } \geq 5.6 \mathrm{mmol} / \mathrm{L} \text { and } / \text { or } \mathrm{RPG} \geq 9.0 \\
\mathrm{mmol} / \mathrm{L} \\
\text { CAN: universal testing; no OGTT; GDM if HbAIc } \geq \\
5.7 \% \text { and/or random VPG } \geq 1 \mathrm{I} .1 \mathrm{mmol} / \mathrm{L} \\
\text { AUS: FPG }<4.7 \mathrm{mmol} / \mathrm{L}=\text { normal; FPG } 4.7-5.0 \\
\mathrm{mmol} / \mathrm{L}=\mathrm{OGTT}(\mathrm{WHO} 2013 \mathrm{criteria}) ; \mathrm{FPG} \geq 5.1 \\
\mathrm{mmol} / \mathrm{L}=\mathrm{GDM}\end{array}$ & $\begin{array}{l}\text { All post COVID-19 modified pathways reduced } \\
\text { GDM frequency. Missed GDMs in Canada gave } \\
\text { similar rates of pregnancy complications, while using } \\
\text { UK and Australian modifications, the missed GDM } \\
\text { group was at slightly and substantially lower risk. }\end{array}$ \\
\hline Seshiah, 2020/India ${ }^{116}$ & $\begin{array}{l}\text { "Single test procedure" for diagnosing GDM: } 2 \mathrm{~h} \text { PG } \\
\geq 7.8 \mathrm{mmol} / \mathrm{L} \text { with } 75 \mathrm{~g} \text { oral glucose administered to } \\
\text { a pregnant woman in the fasting or non-fasting state, } \\
\text { without regard to the time of the last meal (glucose } \\
\text { load can also be taken at home and the pregnant } \\
\text { woman can visit the hospital } 2 \mathrm{~h} \text { after the glucose } \\
\text { ingestion to give a single sample for plasma glucose } \\
\text { estimation) }\end{array}$ & $\begin{array}{l}\text { The economical and evidence based "single test } \\
\text { procedure" of DIPSI is most appropriate for } \\
\text { screening during COVID-19 as performing OGTTs } \\
\text { is resource intensive, the fasting state is impractical } \\
\text { with very high dropout rate. }\end{array}$ \\
\hline Van-de-l'Isle, 2020/UK ${ }^{121}$ & $\begin{array}{l}\text { NICE guidelines methodology }(75 \mathrm{~g} 2 \mathrm{~h} \text { OGTT) vs } \\
\text { RCOG COVID testing for GDM (two-step testing } \\
\text { approach): } \\
\text { First, women with risk factors for GDM (according } \\
\text { to NICE) are tested with HbAlc and RPG at } \\
\text { booking } \rightarrow \text { RPG } \geq I I . I \mathrm{mmol} / \mathrm{L} \text { is diagnostic of } \\
\text { T2DM, and HbAlc value of } 6.8-7.7 \% \text { is considered } \\
\text { indicative of pre-diabetes (women with a value in } \\
\text { this range and a prior history of GDM are managed } \\
\text { as GDM) } \\
\text { Testing at } 28 \text { weeks is recommended and a diagnosis } \\
\text { of GDM is made if any of the following criteria were } \\
\text { satisfied: FPG } \geq 5.3 \mathrm{mmol} / \mathrm{L} \text { or } \mathrm{HbAlc} \geq 5.7 \% \text { or } \\
\text { RPG } \geq 9 \mathrm{mmol} / \mathrm{L}\end{array}$ & $\begin{array}{l}\text { The overall rate of women identified as having GDM } \\
\text { decreased from } 7.7 \% \text { to } 4.2 \% \text { and the COVID- } 19 \\
\text { regimen failed to detect } 57 \% \text { women identified as } \\
\text { GDM }\end{array}$ \\
\hline Nachtergaele, $2021 /$ France $^{1 / 8}$ & $\begin{array}{l}\text { Reference standard testing: OGTT at } 22-30 \text { weeks } \\
\text { according to IADPSG/WHO criteria applying } \\
\text { universal screening } \\
\text { Seven tested algorithms (termed as "Options"): } \\
\text { OGTT only in women with risk factor for HIP, ie, } \\
\text { applying selective screening (Option Sel); } \\
\text { OGTT in women with FPG } 4.7-5.0 \mathrm{mmol} / \mathrm{L} \text { at } 22- \\
30 \text { weeks, applying universal (Option I) or selective } \\
\text { screening (Option I-Sel) } \\
\text { OGTT in women without history of HIP (previous } \\
\text { HIP is considered as GDM) and with FPG 4.7-5.0 } \\
\text { mmol/L at 22-30 weeks, applying universal } \\
\text { (Option 2) or selective screening (Option 2-Sel) } \\
\text { FPG alone measured, applying universal (Option 3) } \\
\text { or selective screening (Option 3-Sel) }\end{array}$ & $\begin{array}{l}\text { Consideration of a history of HIP and measuring } \\
\text { first FPG can avoid more than } 80 \% \text { of OGTTs and } \\
\text { identify women with the highest risk of adverse HIP- } \\
\text { related events }\end{array}$ \\
\hline
\end{tabular}

(Continued) 
Table 6 (Continued).

\begin{tabular}{|l|l|l|}
\hline Author, Year/Country (Ref.) & Pragmatic Approach & Main Results \\
\hline Zhu, 202I /Australia ${ }^{120}$ & $\begin{array}{l}\text { Initial division into groups according to FPG results } \\
\text { (mmol/L): FPG <4.7, FPG 4.7-5.0 and FPG } \geq 5.1 \\
\text { Division into groups according to how GDM was } \\
\text { managed during pregnancy: diet, metformin (MF), } \\
\text { insulin and MF + insulin }\end{array}$ & $\begin{array}{l}\text { HbAlc and FPG are poor screening tests for GDM. } \\
\text { During the COVID-I9 pandemic, the OGTT should } \\
\text { be given clinical priority in high-risk patients, an } \\
\text { HbAlc cut-off of 5.7\% is proposed if it is used for } \\
\text { screening. Elevated FPG is a significant predictor for } \\
\text { needing medical management for GDM and could be } \\
\text { used to enable individualized treatment }\end{array}$ \\
\hline
\end{tabular}

Abbreviations: FPG, fasting plasma glucose; RPG, random plasma glucose; HbAlc, hemoglobin AIc; GDM, gestational diabetes mellitus; OGTT, oral glucose tolerance test; UK, United Kingdom; CAN, Canada; AUS, Australia; WHO, World Health Organization; NICE, National Institute for Health and Care Excellence; IADPSG, International Association of the Diabetes and Pregnancy Study Groups; ADIPS, Australasian diabetes in pregnancy society; RCOG, Royal College of Obstetricians and Gynaecologists; T2DM, type 2 diabetes mellitus; HIP, hyperglycemia in pregnancy; MF, metformin.

they suggest that lower FPG thresholds consistent with the IADPSG criteria (FPG $\geq 5.1$ ) could be considered if resources allow. In India, the use of a "single test procedure", consisting of $2 \mathrm{~h}$ plasma glucose $\geq 7.8 \mathrm{mmol} / \mathrm{L}$ with $75 \mathrm{~g}$ oral glucose administered to a pregnant woman in the fasting or non-fasting state, without regard to the time of the last meal, is considered most appropriate for screening during the COVID-19 pandemic. ${ }^{116}$ Italian guidelines recommended that screening for GDM based on risk factors and FPG forms an acceptable alternative if screening with an OGGT cannot be safely performed. ${ }^{117}$ A French study retrospectively applied in more than 4000 women the seven proposals of the Australian-New Zealand Societies to limit the number of OGTTs during the COVID-19 pandemic. ${ }^{118}$ In their cohort, the option in which OGTTs would be performed in women without history of HIP and with FPG 4.7-5.0 mmol/L between 22 and 30 weeks of pregnancy, applying universal screening, was preferred. This approach offered a good compromise because it reduced the rate of women undergoing OGTTs by more than $80 \%$, while identifying around $70 \%$ of the women with HIP, especially those with the highest risk of adverse outcomes.

Temporarily modified guidelines for GDM screening to limit the number of OGTTs in the context of the COVID19 pandemic will inevitably lead to underdiagnosing of GDM. A retrospective analysis in almost 2000 women diagnosed with GDM showed that $29 \%$ of them had a FPG $<4.7 \mathrm{mmol} / \mathrm{L}$ and would have been missed applying the temporary ADIPS criteria. ${ }^{119}$ Based on these data, the cut-off for the FPG required to identify at least $95 \%$ of GDM cases would be $\geq 4.0 \mathrm{mmol} / \mathrm{L}$. Likewise, a retrospective Australian study ${ }^{120}$ showed that $25.3 \%$ of GDM cases would be missed using the COVID-19 guidelines. A study from the UK examined the differences in detection rate for GDM comparing the methodology recommended by NICE with the temporarily guidelines for screening during COVID-19 pandemic. $^{121}$ They found that the overall rate of women identified as having GDM decreased from $7.7 \%$ to $4.2 \%$ and that the COVID19 regimen failed to detect $57 \%$ women identified as GDM.

\section{Considerations}

There is an ongoing lack of consensus regarding the screening and diagnostic approaches for GDM, with inconsistencies mainly focusing on the appropriate timing of screening, the screening process (one-step vs two-step), the use of a risk-factor-based approach and the different diagnostic criteria for the OGTT.

Up to date, screening for GDM in early pregnancy remains controversial. Observational studies have shown conflicting results on the effect of screening and treatment of GDM in early pregnancy. Smaller RCTs have also not shown conclusive evidence of the beneficial effect of early screening and treatment of GDM. Evidence from large RCTs is needed to evaluate whether early treatment has a positive effect on maternal and neonatal outcomes, without an increased risk for harm such as a higher rate of SGA infants. Awaiting the results of several large ongoing RCTs, screening and treatment of GDM before 24-28 weeks of gestation is currently not recommended in our center. ${ }^{87}$ Instead, a pragmatic approach is proposed for women diagnosed with mild hyperglycemia (FPG 5.5$6.9 \mathrm{mmol} / \mathrm{L}$ ) in early pregnancy. These women are not labeled as early GDM, but we advise a follow-up with a dietician early in pregnancy and provide screening for GDM with a $75 \mathrm{~g}$ OGTT and IAPDSG criteria at 24 weeks 
of pregnancy. ${ }^{87}$ Moreover, there is no clear consensus on which criteria should be used to define GDM in early pregnancy. Several studies have shown that FPG and HbA1c in early pregnancy are a poor predictor for GDM later in pregnancy because of low sensitivity. However, they could still be useful in simplifying the algorithm for GDM screening later in pregnancy.

The debate on the most appropriate screening strategy for GDM at 24-28 weeks of pregnancy is also ongoing. Implementing the one-step IADPSG screening strategy often leads to an important increase in the prevalence of GDM, without conclusive evidence regarding the benefits on pregnancy outcomes compared to a two-step screening strategy with GCT. Adequately powered RCTs are also needed to investigate the impact of prevention and treatment of GDM diagnosed with IADPSG criteria on longterm maternal and childhood outcomes. In several guidelines, selective screening for GDM is still applied, using a risk-factor-based approach or a two-step screening strategy with a GCT to limit the number of required OGTTs. However, most studies reported significant numbers of missed GDM cased when implementing a riskfactor-based approach, with conflicting results regarding the impact on pregnancy outcomes. Another potential selective screening approach is the two-step screening strategy with a GCT. This approach has the potential to reduce the need of an OGTT, but evidence has shown that the threshold of the GCT should be lowered to $7.2 \mathrm{mmol} / \mathrm{L}$ to reach an acceptable sensitivity when using the IADPSG criteria. Other additional screening methods such as FPG or HbAlc often lack sensitivity and/or specificity to be used as the only diagnostic test, but could be helpful as screening test in association with diagnostic tests. In conclusion, the choice between universal and selective screening often depends on the organization of prenatal care, the characteristics of the pregnant population, and the resources of the country, which differ widely internationally.

In pregnant women with bariatric surgery, capillary blood glucose measurements may currently be the most acceptable alternative to the OGTT for GDM screening. The lack of specific guidelines regarding the screening and management of GDM in women with bariatric surgery highlights the need for more research for a better understanding of how to define and treat dysglycemia in a pregnancy after bariatric surgery.

Since 2020, the COVID-19 pandemic is having a major impact on health care delivery, including the screening processes for GDM and overt diabetes in pregnancy.
OGTTs could often not be performed since they involve high risk of exposure and an increased burden on health services. Several guidelines have proposed a pragmatic approach to screen for GDM with HbA1c, FPG or even RPG as an alternative during the COVID-19 pandemic. However, usual guidelines and care should be resumed as soon as the COVID pandemic is controlled.

We performed an extensive narrative review including data from 87 observational studies and RCTs on screening and diagnosing of GDM. We covered several controversial areas, including screening and diagnostic approaches for GDM in early and late pregnancy, after bariatric surgery and in pandemic times such as COVID-19. However, we did not perform a systematic review and could therefore not perform a meta-analysis. We could therefore also not assess the risk of bias of individual studies and did not contact the authors for obtaining missing and unpublished data.

\section{Acknowledgments}

$\mathrm{CM}$ has a PhD Fellowship Strategic Basic Research of the Research Foundation - Flanders (FWO). KB (Katrien Benhalima) is the recipient of "Fundamenteel Klinisch Navorserschap FWO Vlaanderen".

\section{Author Contributions}

All authors in this paper made substantial contributions to conception and design, acquisition of data, or analysis and interpretation of data; took part in drafting the article or revising it critically for important intellectual content; agreed to submit to the current journal; gave final approval of the version to be published; and agree to be accountable for all aspects of the work.

\section{Funding}

No funding was provided for this article.

\section{Disclosure}

The authors declare no conflict of interest.

\section{References}

1. American Diabetes Association. Standards of medical care in diabetes-2021. Diabetes Care. 2021;44(Suppl. 1):S1-S232. doi:10. 2337/dc21-Sint

2. World Health Organization (WHO). Diagnostic Criteria and Classification of Hyperglycaemia First Detected in Pregnancy. 2013.

3. Crowther CA, Hiller JE, Moss JR, McPhee AJ, Jeffries WS, Robinson JS. Effect of treatment of gestational diabetes mellitus on pregnancy outcomes. N Engl J Med. 2005;352(24):2477-2486. doi:10.1056/NEJMoa042973 
4. Landon MB, Spong CY, Thom E, et al. A multicenter, randomized trial of treatment for mild gestational diabetes. $N$ Engl J Med. 2009;361(14):1339-1348. doi:10.1056/NEJMoa0902430

5. Benhalima K, Lens K, Bosteels J, Chantal M. The risk for glucose intolerance after gestational diabetes mellitus since the introduction of the IADPSG criteria: a systematic review and meta-analysis. J Clin Med. 2019;8(9):1431. doi:10.3390/jcm8091431

6. Bellamy L, Casas JP, Hingorani AD, Williams D. Type 2 diabetes mellitus after gestational diabetes: a systematic review and meta-analysis. Lancet. 2009;373(9677):1773-1779. doi:10.1016/ S0140-6736(09)60731-5

7. Grunnet LG, Hansen S, Hjort L, et al. Adiposity, dysmetabolic traits, and earlier onset of female puberty in adolescent offspring of women with gestational diabetes mellitus: a clinical study within the Danish national birth cohort. Diabetes Care. 2017;40 (12):1746-1755. doi:10.2337/dc17-0514

8. O'sullivan JB, Mahan CM. Criteria for oral glucose tolerance test in pregnancy. Diabetes. 1964;13:278-285.

9. Carpenter MW, Coustan DR. Criteria for screening tests for gestational diabetes. Am J Obstet Gynecol. 1982;144 (7):768-773. doi:10.1016/0002-9378(82)90349-0

10. Metzger BE, Buchanan TA, Coustan DR, et al. Summary and recommendations of the fifth international workshop-conference on gestational diabetes mellitus. Diabetes Care. 2007;30 (2):251-260. doi:10.2337/dc07-s225

11. International Association of Diabetes and Pregnancy Study Groups Consensus Panel. International association of diabetes and pregnancy study groups recommendations on the diagnosis and classification of hyperglycemia in pregnancy. Diabetes Care. 2010;33(3):676-682. doi:10.2337/dc09-1848

12. HAPO Study Cooperative Research Group. Hyperglycemia and adverse pregnancy outcomes. $N$ Engl J Med. 2008;358 (19):1991-2002. doi:10.1056/NEJMoa0707943

13. Li-Zhen L, Yun X, Xiao-Dong Z, et al. Evaluation of guidelines on the screening and diagnosis of gestational diabetes mellitus: systematic review. BMJ Open. 2019;9::e023014. doi:10.1136/ bmjopen-2018-023014

14. Benhalima K, Mathieu C, Van Assche A, et al. Survey by the European Board and College of Obstetrics and Gynaecology on screening for gestational diabetes in Europe. Eur J Obstet Gynecol Reprod Biol. 2016;201:197-202. doi:10.1016/j.ejogrb.2016.04.003

15. Cosson E, Vicaut E, Berkane N, et al. Prognosis associated with initial care of increased fasting glucose in early pregnancy: a retrospective study. Diabetes Metab. 2020.

16. Bartha JL, Martinez-Del-Fresno P, Comino-Delgado R. Early diagnosis of gestational diabetes mellitus and prevention of diabetes-related complications. Eur J Obstet Gynecol Reprod Biol. 2002;109(1):41-44. doi:10.1016/S0301-2115(02)00480-3

17. Liu B, Cai J, Xu Y, et al. Early diagnosed gestational diabetes mellitus is associated with adverse pregnancy outcomes: a prospective cohort study. J Clin Endocrinol Metab. 2020;105 (12):e4264-e4274. doi:10.1210/clinem/dgaa633

18. Ryan DK, Haddow L, Ramaesh A, et al. Early screening and treatment of gestational diabetes in high-risk women improves maternal and neonatal outcomes: a retrospective clinical audit. Diabetes Res Clin Pract. 2018;144:294-301. doi:10.1016/j. diabres.2018.09.013

19. Bianchi C, de Gennaro G, Romano M, et al. Early vs. standard screening and treatment of gestational diabetes in high-risk women - an attempt to determine relative advantages and disadvantages. Nutr Metab Cardiovasc Dis. 2019;29 (6):598-603. doi:10.1016/j.numecd.2019.02.007

20. Alunni ML, Roeder HA, Moore TR, Ramos GA. First trimester gestational diabetes screening - change in incidence and pharmacotherapy need. Diabetes Res Clin Pract. 2015;109(1):135-140. doi:10.1016/j.diabres.2015.04.027
21. Hong WY, Biggio JR, Tita A, Harper LM. Impact of early screening for gestational diabetes on perinatal outcomes in high-risk women. Am J Perinatol. 2016;33(8):758-764. doi:10.1055/ s-0036-1571317

22. Hosseini E, Janghorbani M, Shahshahan Z. Comparison of risk factors and pregnancy outcomes of gestational diabetes mellitus diagnosed during early and late pregnancy. Midwifery. 2018;66:64-69. doi:10.1016/j.midw.2018.07.017

23. Harreiter J, Simmons D, Desoye G, et al. IADPSG and WHO 2013 gestational diabetes mellitus criteria identify obese women with marked insulin resistance in early pregnancy. Diabetes Care. 2016;39(7):e90-e92. doi:10.2337/dc16-0200

24. Hughes RCE, Rowan J, Williman J, Ruth D, Hughes CE. Prediabetes in pregnancy, can early intervention improve outcomes? A feasibility study for a parallel randomised clinical trial. BMJ Open. 2018;8(3):18493. doi:10.1136/bmjopen-2017018493

25. Simmons D, Hague WM, Teede HJ, et al. Hyperglycaemia in early pregnancy: the treatment of booking gestational diabetes mellitus (TOBOGM) Study. A randomised controlled trial. Med J Aust. 2018;209(9):405-406. doi:10.5694/mja17.01129

26. The effect of early screening and intervention for gestational diabetes mellitus on pregnancy outcomes. Available from: https:// clinicaltrials.gov/ct2/show/NCT03523143. Accessed March 30, 2021

27. Osmundson SS, Norton ME, El-Sayed YY, Carter S, Faig JC, Kitzmiller JL. Early screening and treatment of women with prediabetes: a randomized controlled trial. Am J Perinatol. 2016;33(2):172-179. doi:10.1055/s-0035-1563715

28. Simmons D, Nema J, Parton C, et al. The treatment of booking gestational diabetes mellitus (TOBOGM) pilot randomised controlled trial. BMC Pregnancy Childbirth. 2018;18(1):151. doi:10.1186/s12884-018-1809-y

29. Harper LM, Jauk V, Longo S, Biggio JR, Szychowski JM, Tita AT. Early gestational diabetes screening in obese women: a randomized controlled trial. Am J Obstet Gynecol. 2020;222 (5):495.e1-495.e8. doi:10.1016/j.ajog.2019.12.021

30. Vinter CA, Tanvig MH, Christensen $\mathrm{MH}$, et al. Lifestyle intervention in Danish obese pregnant women with early gestational diabetes mellitus according to WHO 2013 criteria does not change pregnancy outcomes: results from the LiP (Lifestyle in Pregnancy) Study. Diabetes Care. 2018;41(10):2079-2085. doi:10.2337/dc18-0808

31. Roeder HA, Moore TR, Wolfson MT, Gamst AC, Ramos GA. Treating hyperglycemia in early pregnancy: a randomized controlled trial. Am J Obstet Gynecol. 2019;1(1):33-41.

32. Riskin-Mashiah S, Younes G, Damti A, Auslender R. Firsttrimester fasting hyperglycemia and adverse pregnancy outcomes. Diabetes Care. 2009;32(9):1639-1643. doi:10.2337/ dc09-0688

33. Benhalima K, Van Crombrugge P, Moyson C, et al. Women with mild fasting hyperglycemia in early pregnancy have more neonatal intensive care admissions. J Clin Endocrinol Metab. 2021;106 (2):e836-e854. doi:10.1210/clinem/dgaa831

34. Zhu WW, Yang HX, Wei YM, et al. Evaluation of the value of fasting plasma glucose in the first prenatal visit to diagnose gestational diabetes mellitus in china. Diabetes Care. 2013;36 (3):586-590. doi:10.2337/dc12-1157

35. Mañe L, Flores-le Roux JA, Benaiges D, et al. Role of first-trimester $\mathrm{HbA} 1 \mathrm{c}$ as a predictor of adverse obstetric outcomes in a multiethnic cohort. J Clin Endocrinol Metab. 2017;102 (2):390-397. doi:10.1210/jc.2016-2581

36. Benaiges D, Flores-le Roux JA, Marcelo I, et al. Is first-trimester HbA1c useful in the diagnosis of gestational diabetes? Diabetes Res Clin Pract. 2017;133:85-91. doi:10.1016/j.diabres.2017.08. 019 
37. Boe B, Barbour LA, Allshouse AA, Heyborne KD. Universal early pregnancy glycosylated hemoglobin A1c as an adjunct to Carpenter-Coustan screening: an Observational Cohort Study. Am J Obstet Gynecol. 2019;1(1):24-32.

38. Punnose J, Malhotra RK, Sukhija K, Mathew A, Sharma A, Choudhary N. Glycated haemoglobin in the first trimester: a predictor of gestational diabetes mellitus in pregnant Asian Indian women. Diabetes Res Clin Pract. 2020;159:107953. doi:10.1016/j.diabres.2019.107953

39. Sweeting AN, Ross GP, Hyett J, et al. Baseline HbA1c to identify high-risk gestational diabetes: utility in early vs standard gestational diabetes. J Clin Endocrinol Metab. 2017;102(1):150-156. doi:10.1210/jc.2016-2951

40. van Leeuwen M, Opmeer B, Zweers E, et al. Estimating the risk of gestational diabetes mellitus: a clinical prediction model based on patient characteristics and medical history. BJOG an Int J Obstet Gynaecol. 2010;117(1):69-75. doi:10.1111/j.14710528.2009.02425.x

41. Teede HJ, Harrison CL, Teh WT, Paul E, Allan CA. Gestational diabetes: development of an early risk prediction tool to facilitate opportunities for prevention. Aust $N Z J$ Obstet Gynaecol. 2011;51(6):499-504. doi:10.1111/j.1479-828X.2011.01356.x

42. Benhalima K, Van Crombrugge P, Moyson C, et al. Estimating the risk of gestational diabetes mellitus based on the 2013 WHO criteria: a prediction model based on clinical and biochemical variables in early pregnancy. Acta Diabetol. 2020;57 (6):661-671. doi:10.1007/s00592-019-01469-5

43. Huhn EA, Massaro N, Streckeisen S, et al. Fourfold increase in prevalence of gestational diabetes mellitus after adoption of the new international association of diabetes and pregnancy study groups (IADPSG) criteria. $J$ Perinat Med. 2017;45(3):359-366. doi:10.1515/jpm-2016-0099

44. Adam S, Rheeder P. Screening for gestational diabetes mellitus in a South African population: prevalence, comparison of diagnostic criteria and the role of risk factors. S Afr Med J. 2017;107 (6):523-527. doi:10.7196/SAMJ.2017.v107i6.12043

45. Agarwal MM, Dhatt GS, Shah SM. Gestational diabetes mellitus: simplifying the international association of diabetes and pregnancy diagnostic algorithm using fasting plasma glucose. Diabetes Care. 2010;33(9):2018-2020. doi:10.2337/ dc10-0572

46. Luewan S, Bootchaingam $\mathrm{P}$, Tongsong $\mathrm{T}$. Comparison of the screening tests for gestational diabetes mellitus between "onestep" and "two-step" methods among Thai pregnant women. Obstet Gynaecol Int. 2018;2018:1521794.

47. Meloncelli NJL, Barnett AG, D'Emden M, De Jersey SJ. Effects of changing diagnostic criteria for gestational diabetes mellitus in Queensland, Australia. Obstet Gynaecol. 2020;135(5):12 15-1221. doi:10.1097/AOG.0000000000003790

48. Waters TP, Dyer AR, Scholtens DM, et al. Maternal and neonatal morbidity for women who would be added to the diagnosis of GDM using IADPSG criteria: a secondary analysis of the hyperglycemia and adverse pregnancy outcome study. Diabetes Care. 2016;39(12):2204-2210. doi:10.2337/dc16-1194

49. Rajput R, Yadav Y,Rajput M, Nanda S. Utility of HbA 1c for diagnosis of gestational diabetes mellitus. Diabetes Res Clin Pract. 2012;98(1):104-107. doi:10.1016/j.diabres.2012.02.018

50. Fuller KP, Borgida AF. Gestational diabetes mellitus screening using the one-step versus two-step method in a high-risk practice. Clin Diabetes. 2014;32(4):148-150. doi:10.2337/ diaclin.32.4.148

51. Costa E, Kirckpartick C, Gerday C, et al. Change in prevalence of gestational diabetes and obstetric complications when applying IADPSG screening criteria in a Belgian French speaking University Hospital. A Retrospective Cohort Study. BMC Pregnancy Childbirth. 2019;19(1):249. doi:10.1186/s12884-019-2406-4
52. Feldman RK, Tieu RS, Yasumura L. Gestational diabetes screening: the international association of the diabetes and pregnancy study groups compared with Carpenter-Coustan screening. Obstet Gynaecol. 2016;127(1):10-17. doi:10.1097/AOG.000000000000 1132

53. March MI, Modest AM, Ralston SJ, Hacker MR, Gupta M, Brown FM. The effect of adopting the IADPSG screening guidelines on the risk profile and outcomes of the gestational diabetes population. J Matern Fetal Neonatal Med. 2016;29(7): 1141-1145. doi:10.3109/14767058.2015.1038513

54. Pocobelli G, Yu O, Fuller S, et al. One-step approach to identifying gestational diabetes mellitus: association with perinatal outcomes. Obstet Gynaecol. 2018;132(4):859-867. doi:10.1097/ AOG.0000000000002780

55. Goedegebure EAR, Koning SH, Hoogenberg K, et al. Pregnancy outcomes in women with gestational diabetes mellitus diagnosed according to the WHO-2013 and WHO-1999 diagnostic criteria: a multicentre retrospective cohort study. BMC Pregnancy Childbirth. 2018;18(1). doi:10.1186/s12884-018-1810-5

56. Duran A, Śaenz S, Torrejon MJ, et al. Introduction of IADPSG criteria for the screening and diagnosis of gestational diabetes mellitus results in improved pregnancy outcomes at a lower cost in a large cohort of pregnant women: the St. Carlos Gestational Diabetes Study. Diabetes Care. 2014;37(9):2442-2450. doi:10.2337/dc14-0179

57. Cade TJ, Polyakov A, Brennecke SP. Implications of the introduction of new criteria for the diagnosis of gestational diabetes: a health outcome and cost of care analysis. BMJ Open. 2019;9(1): e023293. doi:10.1136/bmjopen-2018-023293

58. Hung TH, Hsieh TT. The effects of implementing the international association of diabetes and pregnancy study groups criteria for diagnosing gestational diabetes on maternal and neonatal outcomes. PLoS One. 2015;10(3):e0122261. doi:10.1371/journal.pone. 0122261

59. Benhalima K, Hanssens M, Devlieger R, Verhaeghe J, Mathieu C. Analysis of pregnancy outcomes using the new IADPSG recommendation compared with the Carpenter and Coustan criteria in an area with a low prevalence of gestational diabetes. Int J Endocrinol. 2013;2013:1-6. doi:10.1155/2013/248121

60. Meek CL, Lewis HB, Patient C, Murphy HR, Simmons D. Diagnosis of gestational diabetes mellitus: falling through the net. Diabetologia. 2015;58(9):2003-2012. doi:10.1007/s00125-015-3647-z

61. Mirzamoradi M, Bakhtiyari M, Kimiaee P, Hosseini-Najarkolaei A, Mansournia MA. Investigating the effects of treatment based on single high blood glucose in gestational diabetes screening on maternal and neonatal complications. Arch Gynecol Obstet. 2015;292(3):687-695. doi:10.1007/s00404-015-3670-9

62. Satodiya M, Takkar N, Goel P, Kaur J. Comparison of one-step versus two-step screening for diagnosis of GDM in Indian population: a randomized controlled trial. J Obstet Gynaecol India. 2017;67(3):190-195. doi:10.1007/s13224-016-0955-2

63. Hillier TA, Pedula KL, Ogasawara KK, et al. A pragmatic, randomized clinical trial of gestational diabetes screening. $N$ Engl J Med. 2021;384(10):895-904. doi:10.1056/NEJMoa2026028

64. Fadl H, Saeedi M, Montgomery S, et al. Changing diagnostic criteria for gestational diabetes in Sweden - a stepped wedge national cluster randomised controlled trial - The CDC4G Study protocol. BMC Pregnancy Childbirth. 2019;19(1). doi:10.1186/ s12884-019-2547-5

65. Abebe KZ, Scifres C, Simhan HN, et al. Comparison of two screening strategies for gestational diabetes $(\operatorname{GDM}(2))$ trial: design and rationale. Contemp Clin Trials. 2017;62:43-49. doi:10.1016/j.cct.2017.08.012

66. Lowe WL, Scholtens DM, Lowe LP, et al. Association of gestational diabetes with maternal disorders of glucose metabolism and childhood adiposity. J Am Med Assoc. 2018;320(10):1005-1016. doi:10.1001/jama.2018.11628 
67. Lowe WL, Lowe LP, Kuang A, et al. Maternal glucose levels during pregnancy and childhood adiposity in the hyperglycemia and adverse pregnancy outcome follow-up study on behalf of the HAPO follow-up study cooperative research group HHS public access. Diabetologia. 2019;62(4):598-610. doi:10.1007/s00125-018-4809-6

68. Lowe WL, Scholtens DM, Kuang A, et al. Hyperglycemia and adverse pregnancy outcome follow-up study (HAPO FUS): maternal gestational diabetes mellitus and childhood glucose metabolism. Diabetes Care. 2019;42(3):372-380. doi:10.2337/dc18-1646

69. NICE Guideline. Diabetes in pregnancy: management from preconception to the postnatal period. Guidance. NICE. 2015.

70. Health Service Executive of Ireland. Guidelines for the management of pre-gestational and gestational diabetes mellitus from preconception to the postnatal period. 2010.

71. Le Collège national des gynécologues et obstétriciens français et par la Société francophone du diabète. Recommendations pour la pratique clinique: le diabète gestationnel. 2010.

72. Richtlijn van de Nederlands Vereniging voor Obstetrie en Gynaecologie (NVOG) diabetes mellitus en zwangerschap. 2018.

73. Benhalima K, Van Crombrugge P, Moyson C, et al. Risk factor screening for gestational diabetes mellitus based on the 2013 WHO criteria. Eur J Endocrinol. 2019;180(6):353-363. doi:10.1530/EJE-19-0117

74. Arora D, Arora R, Sangthong S, Leelaporn W, Sangratanathongchai J. Universal screening of gestational diabetes mellitus: prevalence and diagnostic value of clinical risk factors. J Med Assoc Thai. 2013;96(3):266-271.

75. Dahanayaka NJ, Agampodi SB, Ranasinghe $\mathrm{OR}$, et al. Inadequacy of the risk factor based approach to detect gestational diabetes mellitus. Ceylon Med J. 2012;57(1):5-9. doi:10.4038/ cmj.v57i1.4193

76. Agbozo F, Abubakari A, Narh C, Jahn A. Accuracy of glycosuria, random blood glucose and risk factors as selective screening tools for gestational diabetes mellitus in comparison with universal diagnosing. BMJ Open Diabetes Res Care. 2018;6(1):e000493. doi:10.1136/bmjdrc-2017-000493

77. Cosson E, Benchimol M, Carbillon L, et al. Universal rather than selective screening for gestational diabetes mellitus may improve fetal outcomes. Diabetes Metab. 2006;32(2):140-146. doi:10.1016/S1262-3636(07)70260-4

78. Avalos GE, Owens LA, Dunne F. Applying current screening tools for gestational diabetes mellitus to a European population: is it time for change? Diabetes Care. 2013;36(10):3040-3044. doi: $10.2337 / \mathrm{dc} 12-2669$

79. Herath HM, Weerarathna TP, Weerasinghe NP. Is risk factor-based screening good enough to detect gestational diabetes mellitus in high-risk pregnant women? A Sri Lankan experience. Int J Prev Med. 2016;7(99).

80. Miailhe G, Kayem G, Girard G, Legardeur H,M, Elbrot L. Selective rather than universal screening for gestational diabetes mellitus? Eur J Obstet Gynecol Reprod Biol. 2015;191:95-100. doi:10.1016/j.ejogrb.2015.05.003

81. Olagbuji BN, Atiba AS, Olofinbiyi BA, et al. Prevalence of and risk factors for gestational diabetes using 1999, 2013 WHO and IADPSG criteria upon implementation of a universal one-step screening and diagnostic strategy in a Sub-Saharan African population. Eur J Obstet Gynecol Reprod Biol. 2015;189:27-32. doi:10.1016/j.ejogrb.2015.02.030

82. Matta-Coelho C, Monteiro AM, Fern EV, Pereira ML, Souto SB. Universal vs. risk-factor-based screening for gestational diabetes-an analysis from a 5-year Portuguese cohort. Endocrine. 2019;63(3):507-512. doi:10.1007/s12020-018-1760-8

83. Hod M, Kapur A, Sacks DA, et al. The international federation of gynecology and obstetrics (FIGO) initiative on gestational diabetes mellitus: a pragmatic guide for diagnosis, management, and care. Int J Gynecol Obstet. 2015;131:173-211.
84. Committee on Obstetric Practice. Practice bulletin no. 137: gestational diabetes mellitus. Obstet Gynecol. 2013;122(2 Pt 1):406-416. doi:10.1097/01.AOG.0000433006.09219.f1

85. Vandorsten JP, Dodson WC, Espeland MA, et al. NIH consensus development conference: diagnosing gestational diabetes mellitus. NIH Consens State Sci Statements. 2013;29(1):1-31.

86. Kleinwechter H, Schäfer-Graf U, Bührer C, et al. Gestational diabetes mellitus (GDM) diagnosis, therapy and follow-up care: practice guideline of the German diabetes association (DDG) and the German association for gynaecology and obstetrics (DGGG). Exp Clin Endocrinol Diabetes. 2014;122(07):395-405. doi:10. 1055/s-0034-1366412

87. Benhalima K, Minschart C, Van CP, et al. The 2019 Flemish consensus on screening for overt diabetes in early pregnancy and screening for gestational diabetes mellitus. Acta Clin Belg. 2019;1-8.

88. Donovan L, Hartling L, Muise M, Guthrie A, Vandermeer B, Dryden DM. Screening tests for gestational diabetes: a systematic review for the U.S. preventive services task force. Ann Intern Med. 2013;159(2):115-122. doi:10.7326/0003-4819159-2-201307160-00657

89. Benhalima K, Van Crombrugge P, Moyson C, et al. The sensitivity and specificity of the glucose challenge test in a universal two-step screening strategy for gestational diabetes mellitus using the 2013 World Health Organization criteria. Diabetes Care. 2018;41(7):e111-e112. doi:10.2337/dc18-0556

90. Dickson LM, Buchmann EJ, van Rensburg C, Norris SA. Fasting plasma glucose and risk factor assessment: comparing sensitivity and specificity in identifying gestational diabetes in urban black African women. S Afr Med J. 2020;110(1):21-26. doi:10.7196/ SAMJ.2019.v110i1.14089

91. Saeedi M, Hanson U, Simmons D, Fadl H. Characteristics of different risk factors and fasting plasma glucose for identifying GDM when using IADPSG criteria: a cross-sectional study. $B M C$ Pregnancy Childbirth. 2018;18(1):225. doi:10.1186/s12884-0181875-1

92. Maesa JM, Fern E-RP, Sanchez-Margalet V, Gonzalez-Rodriguez C. Fasting glycemia as screening tool to rule-out gestational diabetes in low-risk population. Clin Lab. 2018;64(4):461-465. doi:10.7754/Clin.Lab.2017.170920

93. Göbl CS, Bozkurt L, Rivic P, et al. A two-step screening algorithm including fasting plasma glucose measurement and a risk estimation model is an accurate strategy for detecting gestational diabetes mellitus. Diabetologia. 2012;55(12):3173-3181. doi:10. 1007/s00125-012-2726-7

94. McIntyre HD, Gibbons KS, Lowe J, Oats JJN. Development of a risk engine relating maternal glycemia and body mass index to pregnancy outcomes. Diabetes Res Clin Pract. 2018;139: 331-338. doi:10.1016/j.diabres.2018.02.036

95. Cooray SD, Boyle JA, Soldatos G, et al. Protocol for development and validation of a clinical prediction model for adverse pregnancy outcomes in women with gestational diabetes. BMJ Open. 2020;10(11):e038845. doi:10.1136/bmjopen-2020038845

96. Lowe LP, Coustan DR, Metzger BE, et al. Hyperglycemia and adverse pregnancy outcome (HAPO) Study: associations of maternal A1C and glucose with pregnancy outcomes. Diabetes Care. 2012;35(3):574-580. doi:10.2337/dc11-1687

97. Renz PB, Cavagnolli G, Weinert LS, Silveiro SP, Camargo JL. $\mathrm{HbA} 1 \mathrm{c}$ test as a tool in the diagnosis of gestational diabetes mellitus. PLoS One. 2015;10(8):e0135989. doi:10.1371/journal. pone.0135989

98. O'Connor C, O'Shea PM, Owens LA, et al. Trimester-specific reference intervals for haemoglobin A1c (HbA1c) in pregnancy. Clin Chem Lab Med. 2012;50(5):905-909. doi:10.1515/cclm.20 11.397 
99. Khalafallah A, Phuah E, Al-Barazan AM, et al. Glycosylated haemoglobin for screening and diagnosis of gestational diabetes mellitus. BMJ Open. 2016;6(4):e011059. doi:10.1136/bmjopen2016-011059

100. Odsaeter IH, Åsberg A, Vanky E, et al. Hemoglobin A1c as screening for gestational diabetes mellitus in Nordic Caucasian women. Diabetol Metab Syndr. 2016;8(1):43. doi:10.1186/ s13098-016-0168-y

101. Renz PB, Chume FC, Timm JRT, Pimentel AL, Camargo JL. Diagnostic accuracy of glycated hemoglobin for gestational diabetes mellitus: a systematic review and meta-analysis. Clin Chem Lab Med. 2019;57(10):1435-1449. doi:10.1515/cclm-2018-1191

102. Ghosh P, Luque-Fernandez MA, Vaidya A, et al. Plasma glycated CD59, a novel biomarker for detection of pregnancy-induced glucose intolerance. Diabetes Care. 2017;40(7):981-984. doi: $10.2337 / \mathrm{dc} 16-2598$

103. Ma DD, Luque-Fernandez MA, Bogdanet D, Desoye G, Dunne F, Halperin JA. Plasma glycated CD59 predicts early gestational diabetes and large for gestational age newborns. $J$ Clin Endocrinol Metab. 2020;105(4):E1033-E1040. doi:10.1210/ clinem/dgaa087

104. Bogdanet D, O'Shea PM, Halperin J, Dunne F. Plasma glycated CD59 (gCD59), a novel biomarker for the diagnosis, management and follow up of women with Gestational Diabetes (GDM) protocol for prospective cohort study. BMC Pregnancy Childbirth. 2020;20(1):412. doi:10.1186/s12884-020-03090-9

105. Powe CE. Early pregnancy biochemical predictors of gestational diabetes mellitus. Curr Diab Rep. 2017;17(2):12. doi:10.1007/ s11892-017-0834-y

106. Faal S, Abedi P, Jahanfar S, et al. Sex hormone binding globulin for prediction of gestational diabetes mellitus in pre-conception and pregnancy: a systematic review. Diabetes Res Clin Pract. 2019;152:39-52. doi:10.1016/j.diabres.2019.04.028

107. Kwong W, Tomlinson G, Feig DS. Maternal and neonatal outcomes after bariatric surgery; a systematic review and meta-analysis: do the benefits outweigh the risks? Am J Obstet Gynecol. 2018;218(6):573-580. doi:10.1016/j.ajog.2018.02.003

108. Feichtinger M, Stopp T, Hofmann S, et al. Altered glucose profiles and risk for hypoglycaemia during oral glucose tolerance testing in pregnancies after gastric bypass surgery. Diabetologia. 2017;60(1):153-157. doi:10.1007/s00125-016-4128-8

109. Freitas C, Araújo C, Caldas R, Lopes DS, Nora M, Monteiro MP. Effect of new criteria on the diagnosis of gestational diabetes in women submitted to gastric bypass. Surg Obes Relat Dis. 2014;10 (6):1041-1046. doi:10.1016/j.soard.2014.03.013

110. Rottenstreich A, Elazary R, Ezra Y, Kleinstern G, Beglaibter N, Elchalal U. Hypoglycemia during oral glucose tolerance test among post-bariatric surgery pregnant patients: incidence and perinatal significance. Surg Obes Relat Dis. 2018;14(3):34 7-353. doi:10.1016/j.soard.2017.11.031
111. Benhalima K, Minschart C, Ceulemans D, et al. Screening and management of gestational diabetes mellitus after bariatric surgery. Nutrients. 2018;10(10):1479. doi:10.3390/nu10101479

112. McIntyre HD, Moses RG. The diagnosis and management of gestational diabetes mellitus in the context of the COVID-19 pandemic. Diabetes Care. 2020;43(7):1433-1434. doi:10.2337/ dci20-0026

113. McIntyre HD, Gibbons KS, Ma RCW, et al. Testing for gestational diabetes during the COVID-19 pandemic. An evaluation of proposed protocols for the United Kingdom, Canada and Australia. Diabetes Res Clin Pract. 2020;167:108353. doi:10.1016/j.diabres.2020.108353

114. Meek CL, Lindsay RS, Scott EM, et al. Approaches to screening for hyperglycaemia in pregnant women during and after the COVID-19 pandemic. Diabet Med. 2020;38(1):e14380. doi:10.1111/dme. 14380

115. Thangaratinam S, Cooray SD, Sukumar N, et al. Endocrinology in the time of COVID-19: diagnosis and management of gestational diabetes mellitus. Eur J Endocrinol. 2020;183(2):G49-g56. doi:10.1530/EJE-20-0401

116. Seshiah V, Balaji V, Banerjee S. et al. Diagnosis and principles of management of gestational diabetes mellitus in the prevailing COVID-19 pandemic. Int J Diabetes Dev Ctries;2020. 1-6. doi:10.1007/s13410-020-00860-1

117. Torlone E, Festa C, Formoso G, et al. Italian recommendations for the diagnosis of gestational diabetes during COVID-19 pandemic: position statement of the Italian Association of Clinical Diabetologists (AMD) and the Italian Diabetes Society (SID), diabetes, and pregnancy study group. Nutr Metab Cardiovasc Dis. 2020;30(9):1418-1422. doi:10.1016/j.numecd.2020.05.023

118. Nachtergaele C, Vicaut E, Tatulashvili S, et al. Limiting the use of oral glucose tolerance tests to screen for hyperglycemia in pregnancy during pandemics. J Clin Med. 2021;10(3):397. doi:10. $3390 / \mathrm{jcm} 10030397$

119. van Gemert TE, Moses RG, Pape AV, Morris GJ. Gestational diabetes mellitus testing in the COVID-19 pandemic: the problems with simplifying the diagnostic process. Aust $N$ Z J Obstet Gynaecol. 2020;60(5):671-674. doi:10.1111/ajo.13203

120. Zhu S, Meehan T, Veerasingham M, Sivanesan K. COVID-19 pandemic gestational diabetes screening guidelines: a retrospective study in Australian women. Diabetes Metab Syndr. 2021;15(1):391-395. doi:10.1016/j.dsx.2021.01.021

121. Van-de-l'isle Y, Steer PJ, Watt Coote I, Cauldwell M. Impact of changes to national UK guidance on testing for gestational diabetes screening during a pandemic: a single-centre observational study. BJOG. 2020;128(5):917-920. doi:10.1111/1471-0528.16 482

\section{Publish your work in this journal}

Diabetes, Metabolic Syndrome and Obesity: Targets and Therapy is an international, peer-reviewed open-access journal committed to the rapid publication of the latest laboratory and clinical findings in the fields of diabetes, metabolic syndrome and obesity research. Original research, review, case reports, hypothesis formation, expert opinion and commentaries are all considered for publication. The manuscript management system is completely online and includes a very quick and fair peer-review system, which is all easy to use. Visit http://www.dovepress.com/testimonials.php to read real quotes from published authors. 